Portland State University

PDXScholar

\title{
Irish families in Portland, Oregon, 1850-1880 : an immigrant culture in the Far West
}

Michael Kazin

Portland State University

Follow this and additional works at: https://pdxscholar.library.pdx.edu/open_access_etds

Part of the Cultural History Commons, Social History Commons, and the United States History Commons

Let us know how access to this document benefits you.

\section{Recommended Citation}

Kazin, Michael, "Irish families in Portland, Oregon, 1850-1880 : an immigrant culture in the Far West" (1974). Dissertations and Theses. Paper 2230.

https://doi.org/10.15760/etd.2227

This Thesis is brought to you for free and open access. It has been accepted for inclusion in Dissertations and Theses by an authorized administrator of PDXScholar. Please contact us if we can make this document more accessible: pdxscholar@pdx.edu. 
AN ZBSTRACT OF THE THESTS OF Michael Teria for the Master of Arts in History. Preserted, fugust 30, 1974.

Title: Irish Families in Eortiand, Oreqon: 1850-i880. An. In*migrant culture in the Fer West

APPROTED BY MUNBERS OF THE THESIS COMMTHTEE:

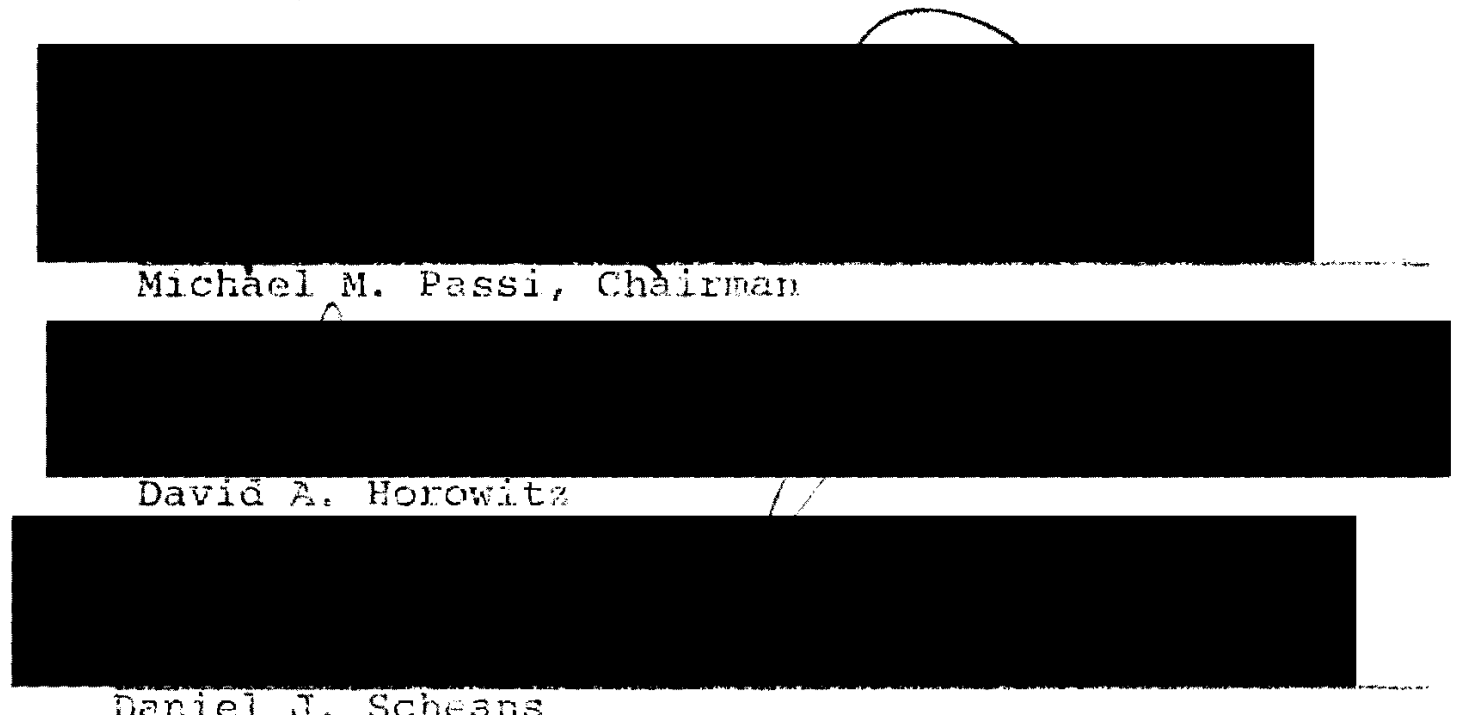

Dariel J. Scheñ

Jnis thesis js an attempt to begin an wanination ar bne scotal. histoxy of immigar farilies in the oities of the wost

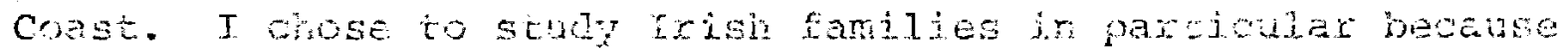
they were che firet grous or migrants to come in farge num

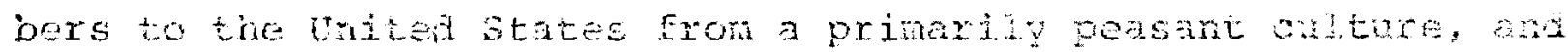

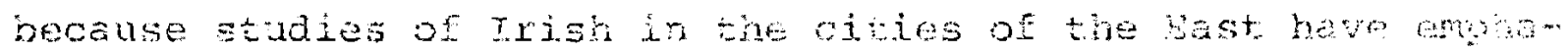
sized their resistance to assimilation into the dombant gng i w

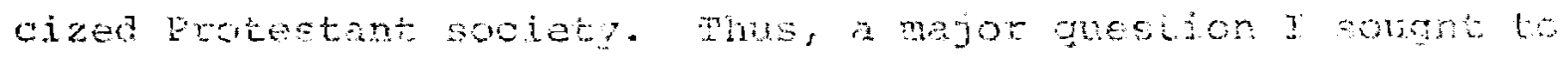

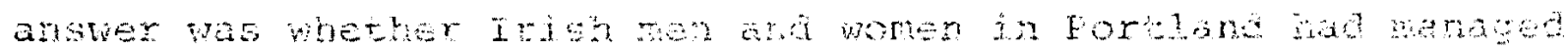


to construct as viable a community and supportive subculture as did their Gaelic relatives in Bosion, Philadelphia, New York, and other cities. I was also anxious to discover what the relationships between the sexes were like in a "frontier city" and to understand how this type of existence affected the patterns of marriage, childbearing, education, and work which are often so poorly understood by historians.

My research was based on a method of compiling data known as "family reconstitution". After drawing up a comprehensive form with spaces for the vital statistics of each husband and wife of Irish birth or parentage married in the only Catholic church in Portland and with room for information about their children, I then investigated the various sources of demographic information on Irish-Americans in nineteenth-century Portland. These included the manuscript census schedules, the church's parish register, Portland's City Directory, and the pupil register of the city's first Catholic school, St. Mary's Academy. Supplemented by issues of the weekly Catholic Sentinel (from February, 1870) and a wide variety of secondary sources, I tried to understand how Irish men and women helped to develop a fast-growing but still relatively small outpost of urban existence.

The characteristic pattern of 19th-century Ireland marked by late marriages, close kinship relations, and the function of the peasant family as a self-contained economic unit was largely destroyed in Portland by 1880. In addition, unlike in Eastern cities, the Portland Irish never formed a geographically defined Irish neighborhood in a town in which every 
non-Inåian was, in a sense, ar inuigrant. However, for a short while, in the $1860^{\prime} \mathrm{s}$ and $70^{\prime} \mathrm{s}$, Portland's Hibernians did create and sustain a rich culture marked by thriving social and religious associations and a Church-sponsored educational system that was highly successful in drawing even many non-Catholic students away from the public schools. Iike their co-nationals in the East, Irish immigrants and their children looking for employment, moved in and out of Portland regulariy in search of work and did not, in general, builc "extended families" of relatives and long-term boarders. They did manage, however, in the face of what was often perceivea as a depraved anarchic environment, to preserve the core of the peasant tradition of piety and discipline in their daily lives. 


\title{
IRISH FAMILIES IN PORTLAND, OREGON: 1850-1880 AN IMMIGRANT CULTURE IN THE FAR WEST
}

\author{
by \\ MICHAEL KAZIN
}

A thesis submitted in partial fulfillment of the requirements for the degree of

\section{MASTER OF ARTS in HISTORY}

Portland State University

1975 
TO THE OFFICE OF GRADUATE STUDIES ANH RESEARCH:

The menbers of the Committee approve the thesis of Michael Kazin, presented August 30, 1974.

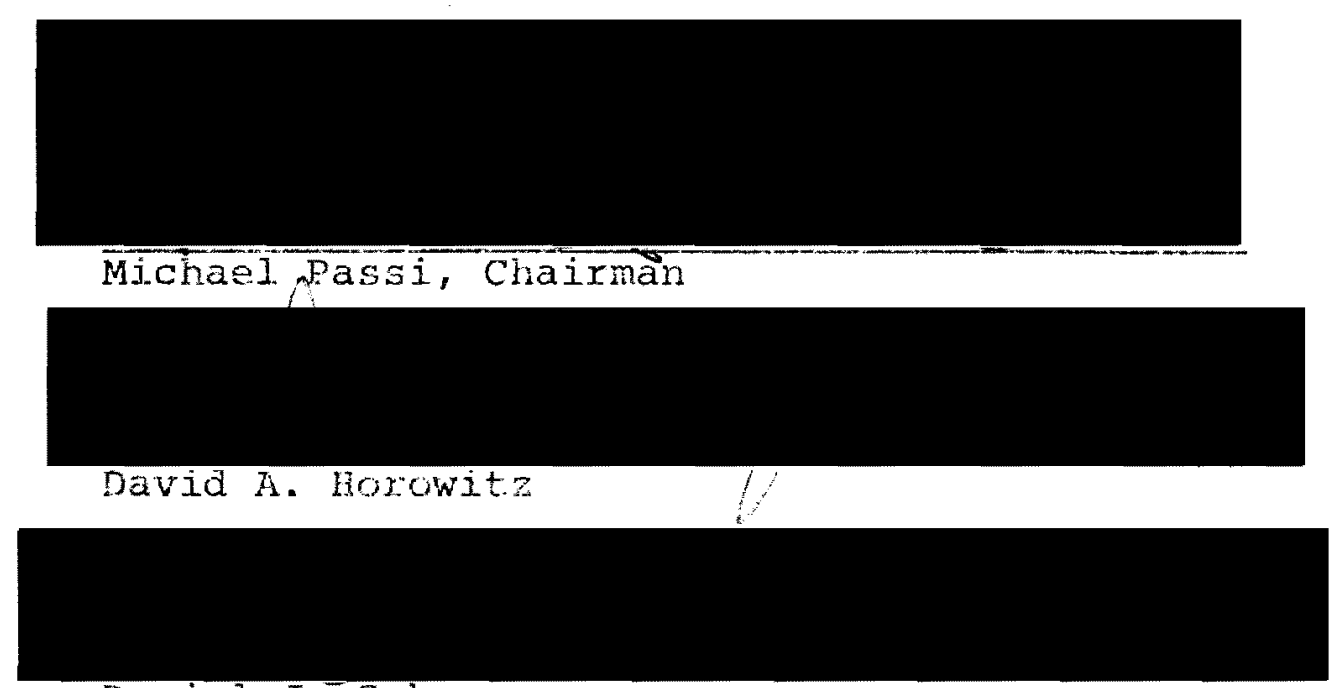

Daniel J. Schears

APPPOVED:

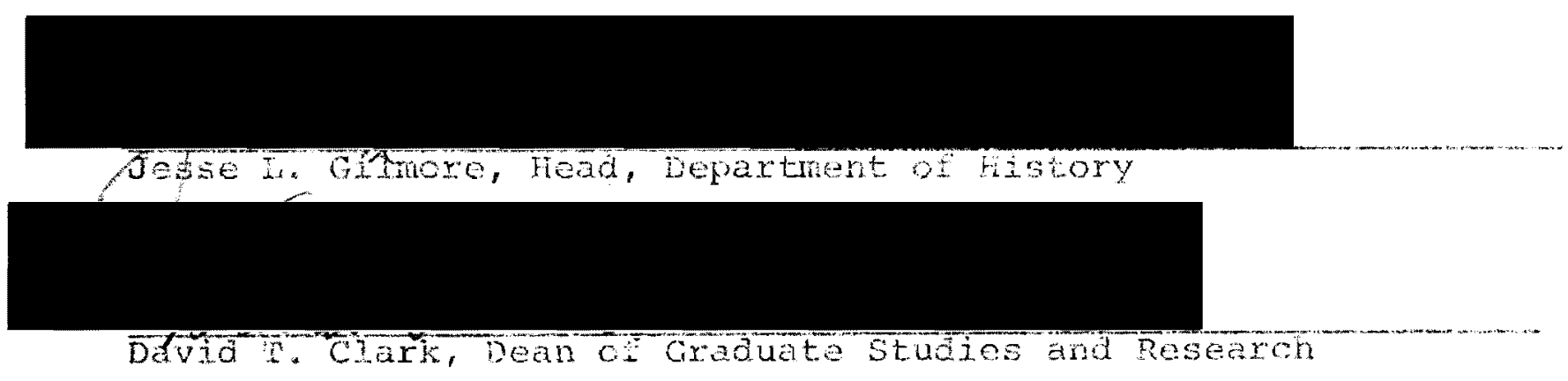


TABLE OF CONTENTS

PAGE

CHAPTER

I INTRODUCTION . . . . . . . . . . . . . . . 1

II FAMILY HISTORY AND HISTORICAL WRITING

ABOUT IRISH AMERICANS . . . . . . . . . 6

III THE MAKING OF THE PORTLAND IRISH . . . . . 18

IV BUILDING A COMMUNITY: 1860-1875 . . . . . 34

V PORTLAND'S IRISH: A LOSS OF POWER . . . . . 55

VI CONCLUSION: THE FAMILY AND ETHNIC SURVIVAL . . . . . . . . . . . . 69

FOOTNOTES .................... . . 73

SOURCES CONSULTED .................... 86

APPENDIX . . . . . . . . . . . . . . . 92 


\section{CHAPTER I}

\section{INTRODUCTION}

The field of social history has blossomed in the last de-cade with research and speculation undertaken into all areas of human experience. Historians have made imaginative use of aera." ographic materials such as census schedules, parish registers, probate court ledgers, and wills, as well as the diaries, letters, and journalistic accounts left by the more literariiyminded. Both sets of sources pose new questions and re-examine old answers about the structure and values of societies and of groups and individuals within them. The new social historians also have introduced the insights of the other social sciences in an effort to illuminate the variables governing people's thoughts and actions in all their richness and complexity. The study of family history is particularly suited for such an interdisciplinary approach. For over half a century before Philippe Aries' study of the development of the concept of childhood in late medieval France exploded onto the scholarly scene in 1950, anthropologists, social psychologists, and sociclogists had been speculating on the cultural differences in family structures and functions and the pre-modern context for the development of the modern nuclear family. ${ }^{1}$ Since that time, studies into family history have emerged with the intention of discovering how changes in families infilience 
changes in the larger society and, in turn, how families have been affected by the more rapid shifts in the polity, economy, and social structure.

Through the creative use of demographic techniques, family historians in this country have uncovered relationships between families and the growth of cities, ${ }^{2}$ between families and the availability of land, ${ }^{3}$ and between family life and the early labor movement, 4 as well as other subjects. What is so far mostly lacking are studies of immigrant families in the United States and their influence on the expanding society to which they came in such large proportions in the three-quarters of a century after 1845.5

This thesis is an attempt to begin an examination of the social history of immigrant families in the cities of the West Coast. I have chosen to study Irish families in particular because the Irish were the first group of migrants to come in large numbers to the United States from a primarily peasant culture, and because studies of Irish in the cities of the East have emphasized their resistance to assimilation into the dominant Anglicized Protestant society. ${ }^{6}$ A major question I had at the beginning of my research was whether Irish men and women in Portland had managed to construct as viable a community and supportive subculture as did their Gaelic relatives in Boston, Philadelphia, and New York. I was also anxious to discover what the relationships between the sexes were like in a "frontier city" and to understand how this type of existence affected the patterns of marriage, child- 
bearing, education, and work which are often so poorly comprehended by historians.

The core of my research is based on a method known as "family reconstitution", which was developed originally by genealogists and refined recently by English and French demographers. ${ }^{7}$ After drawing up a comprehensive form with spaces for the names, dates of birth and death, residences, occupations, parents, and miscellaneous information about each husband and wife married in the Catholic church in Portland and their children (see Figure \#1), I then plowed through the various sources of "vital" information on Irish-Americans in late nineteenth-century Portland. These included the maniscript census schedules for 1850 through 1880, the parish register of the only existing Catholic church in Portland or the surrounding county of Multnomah until 1876, the town's yearly City Directory of most adult male and a few female inhabitants matched up with their occupations (luckily, this was edited and published by Stephen J. McCormick, a leader of the Irish community), and the pupil register of Portland's first Catholic school, st. Mary's Academy. With the help of the issues of the weekly Catholic Sentinel (published in Portland, beginning in February, 1870, as a semi-official publication of the Archdiocese) and a wide variety of secondary sources, I have tried to draw a picture of the role played by Irish families in the making of an Irish Catholic community in Portland and to understand how Irish men and women, as individuals and as members of their national group, helped to 
develop a fast-growing but still relatively small outpost of urban existence.

A lack of sufficient data has engendered several significant shortcomings in this essay. I was unable to find any diaries, letters, or personal records of any sort belonging to members of any of the families I have chronicled. In addition, there seem to be no available documents kept by the various Irish and Catholic benevolent, educational, fraternal, and military associations which were extremely active in Portland in the thirty years covered by this study. The lack of recorded accounts by the people who are the subjects of this study makes my analyses and conclusions rather speculative. This is especially true in attempting to understand the lives of the Irish women of the time who were given little notice by the exclusively male record-takers and journalists. Fs important as it is to avoid evaluating the values and institutions of a century ago by the prejudices and expectations of our time, it is also the duty of a concerned historian to discuss areas that cannot adequately be understood with the available data. Bernard Bailyn's comment in 1957 on the great potential of the then embryonic school of family history is a wise one:

-. the closer one gets to those ultimate building blocks of history the more one is immersed in a knowledge of specific lives and families -- the farther he will find himself from the attractions of traditional formulas, and the more likely is he to see the unsuspected connections and relationships which lead him to new and truer views. 8

Any paper of this size would be impossible without the 
help of others. I am grateful to Nina Sabaroff for struggling to convince me of the central position of women in history; to the Oregon Historical Society for awarding me a grant from the McPhillips Fund which helped cover the costs of research; to Kathy Hanson and Susan Sudduth from the Historical Society who gave me more encouragement and advice than they realize; to Sister Anne Harold of St. Mary's Acadeny who allowed me to use the fragile records of her 115-year-old school; to Marian Fish who interrupted her medical training and the joys of child-rearing to type the final draft; and to my advisor Michael Passi, who taught me to look at history with a respect and sympathy for the usually inarticulate and oppressed majority, but to think with some degree of theoretical precision about the methods and conclusions one employs to stuay them. 
CHAPTER II

FAMILY HISTORY AND HISTORICAL WRITING

ABOUT IRISH AMERICANS

The general conjugal fidelity and reputation for chastity among Irish women were often cited to the honor of the race.?

Typical . . of the Irish immigrant press were frequent rotices by husbands about wives who left their 'bed and board'. 10

The history of Irish immigrants and their descendants has been plagued by much of the same sort of self-glorification and tendency to list events rather than to analyze them that mark so many studies of ethnic groups and racial minorities in the United States. Because the Irish were the first group of predominantly poor and culturally disparate winite migrants to this country, it has been obviously tempting to recount their ascent to skilled occupations and suburban living since World War II as an archetype of the success of Anerican pluralistic democracy. That many of the self-glorifiers almost unconsciously are at odds with each other over significant facts about the experience of Irish-Americans (as the two citations above demonstrate) is one of the casualties of history written from such a point of view.

What is missing in the survey histories of the Irish in this country is a serious attempt to understand the reasons for the particular adaptations the Irish made to the 
changing American reality. The works of Carl wittke, Williant v. Shannon, and George $w$. Potter ${ }^{l l}$ provide articulate summaries of the prodigious poitical activities undertaken in support of the Democratic Party, Irish nationalism, and against Protestant reformers and their crusades for the abolition of slavery, municipal reform, and evangelical religiosity. Little suggestion, however, is offered as to what roles were played by institutions such as the parish church and the saloon in satisfying or allaying the moral and emotional needs of the sons and daughters of Erin.

Too often these works fall back on an entertaining but analytically useless litany of the great Irish men (and a woman or two like Elizabeth Gurley Flynn) who, though upholeing wildy different life-styles and ideologies, all left a lasting impression in their chosen field of work. These synopses include men reknowned in labor orgarizing (Big Bill Haywond), journalism (William Randolph Hearst), urban politics (Alfred Smith; Mayor Richard Daley), the theater (Eugene O'Neil.1), and prize-fighting (John A. Sullivan). Again what is needed but seldom provided by Shannon, wittke, or Potter are insights into why talented Irish-Americans concentrated themselves in certain professions and not others, and how the style and content of their contributions differed from that of their contemporaries and associates who were of other national backgrounds. The Irish-American sociologist, Andrew Greeley, in a recent book, bemoans the lack of a critical historical sense on the part of other Americans of Irish descent. Perhaps he 
would have less cause for woe if, for example, the pioneering role of Irish police was analyzed in terms of how the maintenance of order was furthered by letting members of a "lawless" group like the Irish take responsibility for creating a less rebellious urban environment.

More significant for piecing together the texture of Irish-American social history are the works of Oscar Handlin and Dennis clark, intensive studies of the Irish communities of Boston and Philadelphia respectively, which, though written thirty years apart, bear a striking methodological and stylistic similarity to one another. Both writers approach their material from the standpoint of elucidating the patterns of response and adaptation of a community of Irish who, having just escaped from a famine which claimed the lives of over 158 of their nation's population, 14 were apprehensive about being forcibily assimilated into the lowest level of an overwhelmingly Anglo-Saxon and Protestant society. Handin is especially effective in explaining the rigid Catholicism of most of the Boston Irish:

Their utter helplessness before the most elemental forces fostered an immense sadness, a deep-rooted pessimism about the world and man's role in it... Irish experience generated a brooding recognition that human relationships were transient, subject to the ever-threatening intervention of impersonal evils. . . Buffeted about in a hostile universe by malevolent forces more powerful than themselves, Irish peasants could turn only to religion for consolation. 15

Both Clark and Handin spend a good deal of time detailing the social facts of the immigrant population: where and in what kind of dvellings they lived; in what type of jobs 
they worked; what their relationships were like with local governments and political parties and with other ethnic and racial groups in the city. Both historians fully present the central role of parochial schools and voluntary associations of all sizes and purposes in cementing together different parts of the Irish community and in providing a channel for the aspirations of young people that would have been largely frustrated outside the Irish community. Handin more than Clark seems to realize the continuing cultural dualism that second and even third-generation Irish-Americans lived with even after the virulent nativism of the know-Nothings and their supporters -- an essential factor in the original strength of the Irish sub-culture -- had abated during the Civil war. ${ }^{16}$ Though their books are invaluable to an understanding of the shape of Irish communities in Eastern cities through several decades in the nineteenth century, neither Handin nor clark really confronts the effect of the family on Irish Iife. In the discussions of Irish character which are crucial to an appreciation of the changing lives of their subjects, both men fall back on surface cliches about piety and conservatism on the one hand, and sharp wit and insobriety on the other. Such descriptions could have been taken straight from the pages of any one of several thousand practically identical st. Patrick's Day, orations. 17 The special situation of the Irish woman who often had to function as the head of household when the men in the family were off looking for work and who, in all cases, was almost solely responsible 
for the socialization of children in their infancy and early childhood, is ignored by clark and Handin except for rare references to a marriage rate ${ }^{18}$ or a Protestant newspaper's view of Irish domestics. 19 Beyond a careful description of the economic, political, and social parameters of the Irish experience in Boston and Philadelphia, neither historian helps us to glimpse individual Irish men and women equipped with the unique psychic heritage of the old world who had to cope with the strains and opportunities of a new one. Fortunately, there are a small number of sociologists and anthropologists who have studied the Irish personality and attempted to ground it in the specific characteristics of Irish family life and sexuality which are so important in its formation. The initial work in Irish ethnography was undertaken in rural areas of County clare in the early 1930's and published in two books by the American anthropologists, Conrad Arensberg and Solon Kimball.20 The picture of peasant families that one gets from these volumes has at first glance little to distinguish it from other descriptions of agrarian small landholders anywhere in Europe. The people of rural County clare are devout Catholics and, at the same time, deep believers in various "pagan" spirits and myths which lend a supernatural significance to any unusual event. 21 The work and recreation of male and female adults is rigidly separated by custom with a division of labor agreed to by both parties:

Each feels a right to expect good work from the other, 
in his or her proper sphere. A good husband is a skillful farmer; a good wife is a skillful, willing household worker and auxiliary field hand. The family makes its way through a nice adjustment of these reciprocal roles. 22

Children of both sexes play together as equally subordinate companions of their mother until the age of six or seven when boys are quickly weaned away from their feminine influences and begin to help their fathers and older male relatives in the fields. Girls, in contrast, continue to learn the requirements of their preordained role in the social structure from the women in the family. 23 Marriages are carefully arranged by the male elders (with female advice) who are vitally concerned that a match be one that assures continued stability for both families involved in it. 24

What makes the Irish family distinct or at least different is the character of the bonds of repression and restriction that operate to curb early marriage and the enjoyment of sexual activity. Arensberg and Kimball write about the universal negative attitude held towards sex in county clare. Jokes and stories with a sexual overtone are common but are conventionally larded with a stern morality which, in the tradition of Augustinian asceticisin, mistrusts sensual urges as base and animalistic. One mother of eight declares, "God help us, what is natural can't be wonderful". 25 This attitude has a clear functional utility in Irish history. A people trapped on a small island without the techniques or moral beliefs sanctioning birth control were subject to periodic demographic crises in which large portionz 
of the population died through famine or diseases usually connectea to malnutrition. The amount of land available for the Irish peasantry was squeezed still further by over 600 years of British rule in which absentee landlords shifted labor and resources to make maximum profits from the shifting prices of agricultural commodities on the world market. Therefore, -Irish fathers traditionally held on to their land until a male heir was old enough to get married and to show he could provide adequately for his parents in their last years. Women for their part had to remain perfectly shaste for hide their premarital adventures extremely well) for fear of irrevocably dooming their marriage chances and the right to play any legitimate part in the life of their community. 26

Arensberg and Kimball's work has been corroborated recently by the field research of the ethnographer Johr Messenger who lived on an island off the coast of County clare in the early 1960's.27 The people of the island of Inis Beag would seem to be perfect case studies of "cultural survival" since they have been almost completely cut off from the society of the mainland since their descendants fled oliver cromwell's bloody invasion of Ireland in the mid-17th century. The results of Messenger's research depict a culture even more fearful of sexuality than were the peasarts of County Clare thirty years before. Any suggestion of rudity or the mention of excretory or reproductive functions is considered a flagrant breech of accepted behavior on Inis Beag. Even the styles of dancing on the island forbid partners touching. 28 
Messenger concluded after a wealth of fascinating detail on the intricate patterns of sexual avoidance on the island that much about the Irish personality can be linked to these customs and to the cycle of late marriage, late inheritance, and frequent emigration that either helps to form or causes them. The "cuteness" or common practice of wittily avoiding honesty and intimacy that results is described by Irish novelist Honora Tracy:

An Irish man, sober, will not say what he thinks but what he believes you would like him to think; he is a Inan of honeyed words, anxious to flatter and soothe, cajole and caress. When he has taken a jar or two . . . he will say whatever he judges will give you the greatest offense. In neither case does he reveal his own true thoughts if, to be sure, he has ary. He would be in dread lest you quoted him and the story went round and he got the name of a bold gutspoken fellow, which might be bad for business. 29

Messenger feels this characteristic is common to both men and women on Inis Beag and suggests it exists, altered only in degree, among people of Irish background all over the world. 30 Andrew Greeley agrees with Messenger's harsh assessment and states flatly, "The Irish are a cold, frustrated, sexless, repressed people with little emotional flexibility, and probably no capacity to give themselves in intimate relations." 31

The gulf of methodology and conclusions between social scientists like Arensberg, Kimball, and Messenger and tradj.tional historians like Potter and wittke is not a felicitous one. Each group needs the insights and data that the other provides to present a more rounded explanation of Irish 
behavior in Eire and North America. The greatest failing in the anthropological interpretation is a reluctance to see the inhabitants of County clare or Inis Beag in any kind of comparative or historical context. The geographic isolation of Inis Beag and the unchallenged authority of the Catholic Church there in sanctioning the extremes of sexual repression were not duplicated in 19th-century America or in modern Ireland, societies considerably more secular and heterogenous than Messenger's rocky isle.

No scholar who waxes on about the "Irish character" seems to consider the effects of a new society and a separate history on the millions of Irish who have emigrated across the Atlantic in the last 200 years. Without a careful analysis of the psychosexual reactions of Irish emigrants to exogenous influences, much of the theorizing on cultural retention is premature guesswork and unfair to present-day Irish and Irish-Americans. One sociologist (who is also a Catholic priest of Irish descent) has with little supportive evidence, described his people as incurably burdened with "a general feeling of a lack of love" and an "apparent resignation to loss, with a consequent fear and avoidance of tenderness and intimacy." 32

The pitfalls of interdisciplinary family studies are so apparent only because the possibilities of their application to the resolution of historical questions are so broad. Processes of socialization vary widely in every cultural group, but the need for specificity in drawing conclusions should 
not keep historians from recognizing the common social and psychological needs of all men and women which must be either satisfied in direct ways or else compensated for by other activities. Historians of the family in the United States are just beginning to recognize the particular constellation of factors that determine the character of aggregates of families developing in diverse environments. They believe, as Tamara Hareven writes, ". . that a study of the family provides an understanding of political and social structure, economic developments, and ideology, and assume that the key to an understanding of the interaction between personal development and social change lies in the family." 33

It would be interesting to discuss the work done by American family historians concerning the families of Irish immigrants but, unfortunately, there is very little of it to consider. ${ }^{34}$ Arthur Calhoun, in his three-volume pioneering stab at American family history published in 1917, 35 spends only a few pages on immigrant or Roman Catholic families of any nationality and much of that is marred by his nativist prejudices and a lack of knowledge of the societies from which the immigrants came. In trying to explain the prevalence of many unmarried Irish and German wornen, for example, Calhoun points to the lack of co-educatioral classes in parochial schools, ${ }^{36}$ neglecting facts like the scarcity of Catholic schooling for many immigrant girls and the weight of traditions of late marriage and restrained sexuality that would make his argument insubstantial at best. Calhoun, to his credit, does 
quote an Irish man writing in 1865, who connected the insubordination of immigrant children to their being "ashamed of their humble but honest fathers and mothers", 37 but he closes the whole discussion with a comment that relations between Irish Catholic husbands and wives were not greatly different: from those in Protestant families without giving any evidence for such a significant observation. Calhoun clearly saw his study of "American" families as corsisting primarily of the history of the native-born Protestant majority, and in so doing he was in step with the dominant trend in the historical profession of his time.

To tackle the complicated task of describing the formation, evolution, and activities, both private and public, of an entire people is difficult to do without a large number of monographs on local communities. Following in the lead of sociologists of the "Chicago School" like Lloyd warner and St. Clair Drake, ${ }^{38}$ social historians have concentrateä their efforts in the last 15 years in testing time-worn hypotheses about subjects like the social mobility of workers ${ }^{39}$ and the character of democracy in colonial New England 40 as well as local studies of family structure, values, and behavior. ${ }^{41}$ A gaping hole in the historiography of the American family lies in the study of frontier regions, particularly the Far West, where contemporary developments in social history seem hardly to have made a dent on the traditional fare of sentimental reminiscence and bold legend. Hopefully the growing realization that even as early as the middle and late 
nineteenth century, western cities were "an essential feature of the Western landscape", 42 will enhance their attractiveness as subjects for historical and sociological research. In such future endeavors, I hope the issue of cultural retention or adaptation will be of central interest. The provocative statement of Herbert Gutman's that, "Continuity not consensus counted for much in explaining working-class and especialiy artisan behavior in those decades that witnessed the coming of the factory and the radical transformation of American society", 43 has yet to receive the testing it deserves. 
CHAPTER III

THE MAKING OF THE PORTLAND IRISH

- . it amounts to a body very respectable in weight and numbers. And the persons who go are precisely the persons whom we can ill afford to spare.

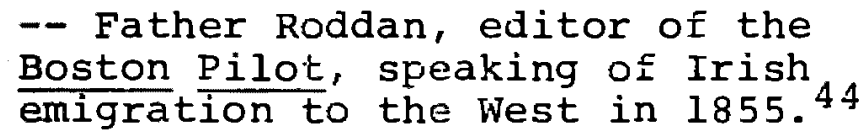

The land from which over a million people fled in the decade after 1845 was the victim of centuries of callous policies meted out by the forces of the largest empire in the modern world. Sharing in the astonishing rise in population throughout Europe in the late 18th century, Ireland's people doubled their numbers from $4,753,000$ in 1791 to $8,175,000$ fifty years later. 45 The economic basis for such an increase collapsed after the end of the Napoleanic Wars in 1815 which had driven the British demand for grain and thus its price to new levels. In a fever driven by fears of depression, absentee English landlords consolidated their farms and evicted many poor tenant farmers and the virtually landless "cotters" to make room for the better profits to be made in raising cattle and other livestock. Millions of poor Irish peasants turned to growing the highly efficient potato on the smail plots of land left to theru, thereby tying their survival to the success of that crop. When the worst of Ireland's periodic potato blights hit the plants at the beginning of 
the growing season in 1845, the specter of widespread famine became a ghastly reality. Emigration from the island had been steady ever since the quantum leaps of population had started in the $1780^{\prime} \mathrm{s}$, but the rate of those leaving after the onset of the Great Hunger made the previous exodus seem like a slow trickle in comparison. 46

Irish society on the eve of the Famine was a primarily rural one with a population of peasant and laboring families who had learned to defend their religion and traditions against the repeated efforts of British administrators and cultural missionaries to obliterate them. For 125 years until 1829, the mere fact of being a practicing Roman Catholic was a criminal offense in Ireland. With a Cromwellian ferocity which had survived the Lord Protector's massacre of the en- . tire Gaelic population at Drogheda in 1649, the imperial parliarnents forbid Catholics to own land, take part in politics, or support their own clergy or churches. In addition, Irisi attempts at winning reforms in their conditions were usualiy greeted with the contempt of conquerors who assumed they had attained an unparalleled level of refinement and civilization. The poet Alfred Lord Tennyson sneered at the Irish: The Kelts are all made furious fools. They live in a horrible island and have no history of their own worth the least notice. Could not anyone blow up that horrible island with dynamite and carry it off in pieces -- a long way off?

In response small numbers of middle-class Irish mounted brave but futile rebellions against British rule; while the majority of the population turned inward to their fami- 
lies and their religion for a measure of self-respect and spiritual sustenance. "Underground" priests, living off the meager contributions of their poor parishioners and serving as a link between widely separated rural communities, became the very antithesis of the aristocratic clergy on the continent who provoked a strong tradition of anti-clericalism among many European peasants. Pre-Christian rituals such as the famous celebratory Irish funeral mingled with a strong Catholic emphasis on guilt and self-discipline to buttress the peasant suspicion of subversive influences whether they emanated from an Anglican missionary or one's own sexual desires. The family's cohesiveness became the centerpiece around which the Irish world-view revolved. As William Shannon observes: - . only a people whose vital concerns were contracted and concentrated in such a narrow sphere would have accepted and enthusiastically upheld an external moral discipline of this kind in the first place. 48

The story of the passage of the Famine refugees to North America has been told often. ${ }^{49}$ Most emigrants made the voyage individually or in couples; the haste of escape and the ruin of many communities wrought by the Hunger and attendant epidemics making any other arrangement impossible for most. 50 As one wolid expect, large numbers of young single men crossed the Atlantic with only strong backs and the freedom from dependents to recommend them to employers, but the substantial surge of emigration of single women that also occurred is more surprising. Few of the domestics and factory-operatives-tobe came aione however: 
If no brother were going out, the parents arranged for the departure of a single girl with a male cousin or relative or neighboring friend, in whose honor they had complete trust, or in the charge of a married couple. 51

Cnce they had arrived in ports from St. John.'s, New Brunswick, to New York City and New Orleans, the Irish immediately became part of the numerous colonies that their countrymen and women who had emigrated in the pre-Famine era had established. There was some friction among earlier and later arrivals because of their class origins and county or region of birth in Eire. The shopkeepers, professionals, and politicians who dominated the life of the Irish ghettos of Eastèrn cities tended to come frorn the more urban and culturally Anglicized North and East of the island and, though over half of them had been farmers or the sons of farmers, they had not experienced the wholesale landlessness and starvation that marked the background of most of the newcomers. The latter were also predominately from the bleak, agrarian expanses of the Western and Southern provinces of Connaught and Munster. In contrast to a sizeable segment of the preFamine emigrants who had acceded more to the political exigencies of British rule, the newcomers were solidly catholic and determined to protect and defend their faith against any encroachments. 52

Andrew Greeley's assertion that, ". . most of the Famine migration came from areas of Ireland where the Irish language was the first language of most people and the only language of many", may be open to question, 53 but the scions 
of cotter and laboring families certainly faced a cultural milieu radically different from the rural and pre-industrial one they had known.

It would be redundant to retell the story of the growth of Irish communities in Eastern cities and the hostile atmosphere generated against this first influx of immigrants. to come to the young nation from a less developed socioeconomic environment. What does interest us are the reasons why most Irish stayed in Eastern cities and what were the motivations of those immigrants who left a more secure situation and came West.

The Irish were slow to leave the metropolises and railroad camps of the Eastern Seaboard because, by and large, they lacked the knowledge and funds imperative in frontier regions. Few members of the Famine generation had any experience in farming any crop except potatoes; while many others had been itinerant laborers with no familiarity with the management of livestock or machinery. What savings the illpaid domestics or construction workers were able to amass often went to support their less fortunate kin back in Eire or to protect themselves from accident, illness, or the ignominy of an unmarked grave through regular contributions to the numerous benevolent societies that sprang up early in the Irish sections of Boston, New York, Philadelphia, and other cities. ${ }^{54}$ Moreover, removal to the west in the ante-bellum period meant leaving poor but well-established communities of friends and family; churches, stores, and newspapers that 
catered directly to the immigrant's needs. Fortune may have shimmered in the West, but where could a man or woman find the sociability and spiritual stability that were often the only respites from a life of unremitting toil?

Understandably, those Irish who did make their way to the rural Midwest and the Pacific coast tended to have been relatively successful and to have stayed for some years in their initial American places of residence in the East. Sister Justille McDonald examined the backgrounds of 150 Irishborn male settlers in wisconsin in the late nineteenth century and reported that they had spent an average of seven years in other states before moving West. Most of the mer: listed New York or Massachusetts as their last state of residence. 55

There is no in-depth study of the Irish community that mushroomed in San Francisco during the Gold Rush, but one impressionistic account characterizes it as remarkably affluent, lea by owners of construction, food wholesaling, real estate, and transport firms who had cornered a large chunk of their particular markets when the city was young. Irish miners were certainly prevalent in the numerous discoveries of precious minerals in the 1840's, '50's and '60's. Two of them, Peter O'Riley and Patrick McLaughlin, even received credit and a fortune in silver for discovering the rich Constock Lode in Nevada in 1859.56

Perhaps representative of many Irish men who went West was one Themas Kerr who kept a fascinating diary of his voy- 
age around Cape Horn to San Francisco in 1849 and 1850.57

Kerr had left his home in Dundalk, County Louth. (near Ulster) to find gold. However, his personality was very unlike the image of a young adventurer off to seek riches with a devilmay-care attitude towards conventional morality and familial responsibility. Kerr, who had been to school for an indeterminate period of time and had worked as a bookkeeper and clerk in Ireland, was faithful to the utterly devout and somewhat guilt-ridden religion of his ancestors. After drinking with some "yankee" sailors at a party in Valparaiso, Chile, on the way up the coast to California, Kerr is flustered and ashamed. He writes in his diary that one of the "yankees" had recited jokes "which were not of the most pleasing language", and concludes resolutely, "I trust that I shall never be induced to spend a sabbath in such a profane manner again. - ." 58 A few days after he arrives at his destination, Kerr hears that several houses of gambling and prostitution have accidentally burned down and writes in grateful terms about what he sees as the cleansing act of an avenging Providence. 59

Above all, Thomas Kerr's diary shows him to be a man whose thoughts are dominated by thoughts of his family and his financial future. After several months in California with the planned search for gold unexplainedly squelched, Kerr is despondent:

- - now when I see that I am in this country since Easter day last earned I may [say] comparatively nothing to what my expenses were; and again I see I 
have a Wife and child depending upon my exertions, yes a wife I love more than worlds. It drives me almost to madness $6 \dot{0} \cdot \cdot$ may God direct my future goings
for the better. After a long sickness, Kerr's spirits and the size of his bankroll improve, and he is able to send for his wife and children.

At the end of the diary, Kerr has been reunited with his ramily for over six months. Despite the vigorous expressions of love for his spouse emphasized earlier, he mentions her later hardly at all and, when he does, always calls her "Mrs." in lieu of her given name. His emotions seem directed more towards his sons whom he speaks of often (and always by their first names). 61 Thomas Kerr went on to become a moderately successful salesman for wholesale grocers in the Bay Area and died jin 1888 in San Francisco at the, by that day's standards, old age of sixty-three. 62

The first Famine-era Irish immigrants to make their way to the growing metropolis of Portland in the oregon Territory in the early 1850's found a dynamic core of Catholic clergy to welcome them. For almost three decades, the priests had been vigorously contending with Methodist missionaries for the allegiance of fur traders, trappers, and farmers who began to fill up the Pacific Northwest after the opening of the market in beaver pelts in the second decade of the century. Dr. John McLoughlin, a devout Catholic and the agent for the fur-trading Hudson's Bay Company in the Northwest, helped settle some of his French-Canadian employees on the fertile 
lands of the willamette valley. There, some 30 miles from the site of the city of Portland, was formed the settlement of st. Paul, an almost exclusively Catholic community. ${ }^{63}$ The leaders of the Faith in the Oregon Territory (which then comprised the present-day states of Washjington, Idaho, and part of Montana, as well as oregon) were two young and vigorous Quebecois missionary priests, Francis Norbert Blanchet and Modeste Demers, who began their work in 1838. Blanchet stayed on, serving as Archbishop of the area until his death in 1883.64

Portland developed as a city because of its unique position near the confluence of two wide and navigable rivers, the willamette and the Columbia. Farmers and lumbermen trying to move their products to larger markets, miners of precious metals seeking provisions and a recreation spot, and federal troops needing a rear area from which to mount attacks on the numerous Indian tribes in the region all contributed to the economic raison-d'etre of the town in the 1850's. Though it had to weather two severe slumps in 1853-5 and 1859, caused by price cuts in Eastern manufactured goods sold by rival merchants in San Francisco, Portland businessmen could boast by 1860 of a growing commerce and a population rapidly expanding from the census total of $2,874.68$

Portland had much to recommend it in the mid-nineteenth century to those Irish immigrants who were able to make their way across the plains and mountains or around the ocean perimeter from the East. Profit-making opportunities abounded 
for men with some imagination and a little capital, and the area's identity as an entrepot for the commerce of the entire Northwest provided small merchants with a ready-made market for their goods and services. Most women had little independent role to play in the economy of the time, but a minority of single or widowed Irish women did achieve some financial security by running boarding-houses for the hoards of single male laborers who flocked to the city or by making dresses for the wives of the city's more affluent citizens.

A Catholic Church, the essential institution of an Irish community, was founded in 1851, when Irish-born Father James Croke performed midnight mass on Christmas Eve in a small, one-story house on the edge of the woods at 5 th and Couch streets. 66 The structure was a modest beginning but took its place as only the third church in town, the Methodists having built the original house of worship only a year and a half before. ${ }^{67}$ Thus the small group of under fifty Irish Catholics in Portland could experience the egalitarian feeling of being in on the building of a new city -- something their co-nationals in Boston and New York might have envied as they struggled to survive with dignity in environments controlled by firmly entrenched Protestant governing classes. 68 The few Irish couples who were married in the Church of the Immaculate Conception in its first decade bore the marks of their 6,000 mile odyssey to the Pacific Northwest. of the sixteen marriages between 1852 and the middle of 1860 in which the nationality of at least one of the spouses is 
known, the average age at which Irish-born men were wedded was 31.7 years, a figure close to that believed to have prevailed in Ireland at the time. 69 In contrast the non-Irish husbands of Irish women were only 27.4 years old on the average when they took the nuptial vows from Father croke or one of his assistants. For their part, Irish-born women averaged a correspondingly high age of 25.2 years at their weddings. 70 Clearly, the first Irish families in Portland were formed by men and women who had followed an important tradition of the kinship system of their homeland.

Crucial to understanding the character of urban populations in the nineteenth-century is the question: how long did people stay in cities and what factors made them stay or leave? Stephan Thernstrom anä other historians have concluded that Eastern cities were places of constantly shifting numbers of working people; while the more prosperous groups "persistea" Ionger in the same urban centers. Thernstrom used his findings to partially explain the lack of a working class with socialist politics in the United states:

One reason that a permanent proletariat along the lines envisaged by Marx did not develop in the course of American industrialization is perhaps that few Americans have stayed in one place, one work-place or even one city long enough to discover a sense of common identity and common grievance. 71

In Portland, the Irish up to 1880 were largely a population of unskilled and skilled workers and their fanilies. The "persistence rate" of the first group of marriages studied (1852-1860) shows Thernstrom's thesis to be of validity 
in respect to this one segment of the relatively isolated Western city's working class. Only seven of the original eighteen couples who were married in the 1850's in the Catholic Church on the edge of the forest were still in Multnomah County in any form (including deaths to one spouse) in 1870. The same seven remained to answer the census enumerator's questions in 1880. The second group of Irish couples (18601870) had a slightly higher rate of persistence. Of $93 \mathrm{cou}-$ ples chronicled, $44 \%$ were in Portland or the surrourding county in June of 1880 . Almost without exception, the occupations of the male heads of the first and second generation Irish families who left were those of "laborer" or a trade such as "teamster" or "drayman" which did not require knowledge of an easily marketable craft such as carpentry or boot-making.

Though at first glance, the lack of urbanized regions of comparative size within hundreds of miles of Portland would make the high rate of those leaving seem rather incredible, the character of the city's economy explains the statistics to a large extent. Portland in 1880 was still a city of preindustrial pursuits. Laborers on the docks, the railroads, or other construction projects, and men who transported the goods that circulated through the city were often employed irregularly and for wildly fluctuating wages. The lack of security attendant on such jobs made the option of following a mining strike or moving south to the more populous area around San $\bar{r}$ rancisco more possible than it might have been 
in an Eastern industrial city with steadier wages and a social structure of entire families working in the same factory or mine. The minority of Irish women who did not work exclusively in the home faced an equally if not more precarious employment situation. As Mary Wright, a recent student of Portland social history, has suggested:

Commerce and shipping, which were strong in Portland, were not open to women, and the days when women entered the white-collar world as office and sales workers were still ahead. Women in Portland therefore worked in areas typically their cwn: domestic service, teaching, nursing, prostitutigh, the sewing trades and running boarding houses.

Navigable rivers, dry weather roads, the existence of smaller settlements in northern oregon and southern washington such as Salem, Astoria, Oregon City, St. Helen's, and Fort Vancouver, and a regular steamship line to San Francisco all made it possible to leave and return to Portland without lindue hardship by the mid-1860's. 73

The Irish families who remained in Portland twenty years or more experienced a good degree of improvement in their economic status. When Arthur Fahie of County Tipperary was married to Bridget Devlin of County Derry in November, 1852, at the church-house of the Immaculate Conception, Fahie was a 32-year-old carpenter with no real or personal property to his name. 74 Sometime in the next ten years, he managed to open a shop in the business district at 2 nd Avenue and Ash Street and, by 1875, was able to build both a two-story house valued at $\$ 2500$ for his family and two stores worth $\$ 5000$ each six blocks from one another in the 
downtown area. The City Directory two years later (which had listed his occupation as "carpenter" every year since its first appearance in 1863) recognized Fahie's elevation to the ranks of the community's richer men by labeling him a "capitalist". The Fahie family grew steadily during these years as Bridget (who was twenty-two at her marriage) gave birth to eight children in the fourteen years from 1853 to 1869. Unfortunately, three of her babies died before their second month, a not uncommon experience for women of all classes at the time. In fact, of the 39 children born to the eighteen Irish couples married in the church up to 1860 , seven of them (almost 18\%) died before they reached the age of five.

The same group of founding Irish mothers and fathers in Portland included men who became influential in the government of the city in the next quarter-century. William cree, who married 17-year-old Mary Pheelan in 1858, a decade later became a Democratic leader and the first Irish-born city councilman in a county political system thoroughly ruled by Protestant Republicans (thought the state vote, influenced by ex-Southerners who had settled in southern Oregon, was more evenly divided along party lines during the Gilded Age). ${ }^{75}$ William P. Burke, born in Ireland in 1828, became a prosperous shipwright by 1860 (with $\$ 7200$ in real and personal property) and rose to be Commissioner of Police two years before he died in 1875. His wife, Catherine VileY, had come over the mountains from wisconsin in 1850-51, her 
first husband dying on the way. She and Mr. Burke had no children of their own, but the only son of her first marriage, Joseph R. Wiley, became a leading figure in the Irish and Catholic communities in the $1870^{\prime} \mathrm{s}$, having started as a police captain under the tutelage of his step-father.

Most of the families headed by unskilled or semi-skilled workers from this group left Multnomah County within ten years of their marriage date. Only two husbands of Irish birth, a laborer and a teamster, remained with their families in the city through the 1880 census. The teamster, Patrick Hogan, lived to see his two sons start the climb up to a skilled trade -- one as an apprentice harness-maker; the other in a printer's shop. His wife Mary, a native of County Monaghan in the northern part of Ireland, remained solely a housekeeper as did all but a handful of the Irish-born wives married in Portland from 1852 to 1870. The Hogans, like over two-thirds of Portland's Irish families in 1860 and 1870 , lived without boarders in a wooden, single-family dwelling. 76 With an influx of single male laborers during the railroad boom of the late 70's and a general leap in population, the percentage of Irish taking in boarders increased slightly to $27 z$ in 1880 (from $25.8 \%$ and $22.9 \%$ in $1870 ; 1860$ ). 77

The Irish in Portland were, by 1860, a little less than 103 of the total city population of 2874.78 The men were scattered occupationally among a wide variety of pursuits, from merchant to laborer. Only in the latter category, however, were they predominant, making up $46 \%$ of the white male 
laborers in the city (56 of the 131 Irish-born men in Portland were laborers in 1860).79 OE the 101 Irish-born women in Portland, only 20 of them had a job outside the home, and 15 of these were domestic workers in the homes of middleclass (usually Protestant) Portlanders. 80 Within this overall picture of an Irish contingent overwhelmingly at work in the lowest stratum of a fast-expanding economy, the more prosperous of the 74 Irish families in Portland formed a comparative elite. Owners of the small number of Irish-owned businesses, including at least nine saloons), 81 almost all of them able to read English, and steady supporters of their Catholic Church and its Irish pastor, these families were financially poor but were already beginning to build an educational and associational community that would rival any in the metropolises of the East. 


\title{
CHAPTER IV
}

\section{BUILDING A COMMUNTTY: 1860-1875}

\begin{abstract}
"The day is near at hand when the widely scattered sons and daughters of a nation will be drawn together by a bond of love, faith and hope, unparalleled in the history of the world. Year after year, while disseminating abroad the teachings of the true Church, they revisit the scenes from whence sprang the indellible impressions which lead them to show, by practice as well as precept, an example of love and fidelity to their Creator and their country which no other people have ever done. The Almighty ruler of Heaven and earth has given to them the honor of being a nation of missionaries."

-- Catholic Sentinel (of Portland), March 12, 1870
\end{abstract}

The 1860's was the period when Portland's economy matured to the point where it became a stable city and the indispensable center of the Pacific Northwest region's productive life. The oregon Steam and Navigation Company, founded in 1860, boosted the integration of the farming and mining areas of the inland plains and mountains with the cornercial resources of Portland. 82 Manufacturing was never a strong part of Portland's economy in the nineteenth century, but the city did contain 307 industrial establishments by 1870. These were almost entirely food processing or small shops producing for the local market; in all, they enployed only 1,142 workers (an average of less than four per shop).83 The boundaries of the city were stretching along the west side of the willamette River, and, on the other side, the 
construction of the East Side line of entrepreneur Ben Holladay's Oregon and California Railroad produced a boom in the town of East Portlana. River traffic multiplied dramatically. ${ }^{84}$ By 1869, the Irish-born editor and publisher of the City Directory, Stephen J. McCormick, could proclaim confidently, "Portland has ceased to be an experiment." 85

For Portland's Irish, the 1860's brought the first manifestations of the relationships and institutions that established them as a distinct cultural entity in an increasingly cosmopolitan setting. Portland in 1870 was a town of 9,565 peopie of widely diverse national origins. Fully onehalf of the population was either foreign-born or had at least ore foreign-born parent; and the Irish formed over $30 \%$ of almost 3,000 immigrants to the city. They were an equally significant portion of East Portland's citizenry. Thus the religious, educational, charitable, and fraternal projects begun by Irish men and women became models for less numerous and later inmigrant groups to follow as well as the foundation of a thriving multi-national Catholic community network.

The first priority for the most determined and devout Irish in early Portland was to construct a system of Catholic schools. In the fall of 1859, twelve nuns from the order of the Holy Names of Jesus and Mary set out from their convent in Montreal at the request of Archbishop Blanchet and, within a month, arrived in Portland. Their mission was to establish primary and secondary schools in the state of oregon, adnitted to the Uniun only that year. 
In the face of some antagonism from militant protestants in the town who were struggling to keep a public school open for more than a year at a time, ${ }^{87}$ the sisters opened the new St. Mary's Academy in November, 1859. The first class of six female students at the school went to class in a small house at the southern edge of the city, owned by the Archdiocese. Only three of the girls in the first class were Catholics (two of Irish parents, one of German), a proportion that increased but did not ever completely dominate the student body in the first three decades of. St. Mary's existence. The school, in the tradition of parochial schools and by financial necessity, was always open to non-Catholics, and many Protestant and even Jewish parents clearly admired the standards of discipline and training that the sisters set for the young women in their charge. 88

Most Irish Catholics in Portland who could afford the $\$ 5-\$ 10$ tuition per semester ${ }^{89}$ sent their daughters to st. Mary's when they had reached the age of six or seven (though several boarders were as young as four). Since wage rates fluctuated widely in a frequently unstable economic climate, this could be either difficult for a laboring family to pay or well within its reach. One contemporary report (in January, 1871) listed wages for servants as $\$ 30$ a month, but since this came at a time when men seeking employment were reported to be flooding the city, 90 it may be unreliabie as a guide. Whatever the circumstances, girls with Irish names were usually one-third to one-half of the pupils at St. Mary's 
in its first twenty years. Daughters of Irish immigrants regularly won most of the school prizes and exhibited their inherited flair for colorful oratory at commencement exercises and at the frequent oral examinations which were open to the public. 91

A few wealthy Portland Catholics could afford to send their sons to California or to the East for education in Jesuitrun academies. However, most of Archbishop Blanchet's flock had to wait for the opening of 'St. Michael's College for Bôys which opened in 1872 to satisfy the secondary education needs of their male children.92 From August, 1861, to early 1871, the hard-working sisters from Montreal had operated a primary school for boys, st. Joseph's, adjacent to the female academy but had to give up the effort after three of the twelve nuns died within a two-month period in late 1870.93

Al]. three schools, and the two orphanages the sisters maintained in the city, despite the Gallicized background of most of the teachers (the nuns' Quebec origins were complemented by the principal and head instructor at st. Michael's, Rev. A.J. Glorieux, who was a Belgian) were propped up in iarge part through the moral and financial support of the Irish community. Irish associations took frequent opportunities to include the schools in their events:

The pioneer Hibernian Society of Portland, having heard of the ever-ready. skili of the nuns at St. Mary's, sent a delegation of their society to the Academy in 1861, requesting the sisters to make badges for their organization -- green satin scarfs ornamented with gold bullion. This interview somehow developed into a custom which gained prominence 
with recurring anniversaries of Ireland's great patron, st. Patrick. The new and spacious chapel was dedicated on March 17, 1863. The Hibernians wearing brilliant regalias filled its nave. The first panegyric voiced within its walls was one to st. Patrick, with a spirited complement of music and anthems by the Academy choir.

The Hibernian Benevolent Society, organized in February, 1860, was only one of several Irish-dominated and exclusively male associations that formed an interrelated pattern of parish leadership in the 1860's and early $70^{\prime} \mathrm{s}$. The Hibernians were followed in 1863 by the Fenian Guards, a militia group $^{95}$ renamed the Emmet Guards later in the decade (after a reknowned Irish revolutionary figure), and were joined in 1865 by the Catholic Library Association, described by one historian as "the principal parish organization" until the development of regular sunday Schools later in the century. 96 The ensuing decade saw the emergence of a blizzard of similar organizations: the charitable saint Vincent de Paul society (1869); the Catholic Social Union, Catholic Literary Union, and Catholic Library Society (short-lived discussion clubs from 1874-1876); the Knights of St. Patrick (1871); numerous volunteer fire companies; and various committees formed to raise money or to plan for a new cathedral, a parish-sponsored hospital, or a fund-raising fair. 97

The functions served by these associations were obviously varied and ali significant, but they all shared one feature wiok few of the historians of such groups have mentioned. The scciety the immigrants came from was marked by a sharg division of the sexes in the sphere of recreation. 
Both Arensberg and Messenger describe the active social life of drinking, story-teliing, and card-playing enjoyed at night by rural Irish mer and the lack of any equivalent pleasures for their wives, mothers, and daughters. 98 Messenger feels much of the sexual character of the Irish can only be understood when connected with the tradition of "male solidarity", of which he writes, ". . it is instrumental in delaying marriage and making for marital maladjustment." 99 He quotes a recent comment by a female critic on the play Grania by the 19th-century Irish playwright, Lady Gregory:

Grania is . . a play in which a woman is ousted from an emotional relationship between two men. The 'love' is that of man for man, of brother for brother; it is $10 y-$ alty to the warrior band, and a corresponding resentment of the woman who takes away the warrior's ireedom, makes trouble with his comrades, distracts him from his purpose in life.l00

Though their organizations were intended to further the interests of the entire Irish anö Catholic populations, the internal character of the Portland Hibernian Benevolent Society and its successors bore several similarities to the male groupings in rural Ireland. Small businessmen and skilled craftsmen were typically the most active members of the various societies. Due to the nature of their work routines, they had more contact with other Irish men during the day and were relatively freer than wage laborers to arrange their hours of work to include associational activities. A few men must have been busy almost every night of the week. For example, Daniel J. Malarkey, a prosperous grocer, was, in 1873, an officer of the Catholic Building society, the Saint 
Vincent de Paul Society, and the Catholic Literary and Doctrine Society (the former Catholic Library Association), as well as being a member of the Hibernian Society and of both a militia and a volunteer fire company. Women were occasionally invited to a ceremonial meeting of one of these societies, but the routine business and fraternal activities were barred to them.

Several times a year, the Irish-led associations banded together the entire Irish and Catholic community in events such as picnics and parades. In early June, 1873, the Portland Hibernian Society drew from 1200 to $1500 \mathrm{men}$, women, and children to their annual picnic held near vancouver, across the Columbia River in the Washington Territory. An Irish band from East Portland played "national airs" on the steamer ride up to the picnic site and, upon their arrival, young participants of both sexes took part in a wide range of games and races including a fat man's race, a greased pig chase (the prize being a massive pig), a wheelbarrow race, and a ladies' target shooting match of which one reporter remarked, "The young gentlemen seemed particularly anxious to see their favorites secure the prize." A long display of skyrockets brought the day's events to a close. 101

A more formal annual community event was the nammoth st. Patrick's Day parade, a common sight in the Gilded Age in every American city with an Irish contingent of at least moderate size. In Portland, the traditional display of all the fraternal and benevolent associations in ceremonial uniform 
was complemented by the participation of the entire Catholic clergy and of most city and county officials. 102 The parade typically ended at the parish church or in the chapel at st. Mary's where hymns were sung and testimonials given to the undying unity of piety and patriotism -- the highest ideal any Irish man or woman could strive for. The St. Patrick's Day celebration capped each eventful year for Irish "joiners" and their kin who worked hard to insure that for its size, ". . there were few parishes in the country that provided more social activities for its members than that of Portland." 103 With a congregation of 1000 in 1870 , the Church of the Immaculate Conception had the most parishioners of any house of worship in Portland. What it lacked, however, in an age when printed media was the sole means of uniting and persuading large numbers of people to a point of view, was a local newspaper. On February 5 of that year the weekly Catholic Sentinel began to fill the need. Officially the approved journal of Archbishop Blanchet's far-flung ecclesiastical province, 104 the Sentinel actually served as a local Portlandarea weekly, competing with several Protestant papers and the plethora of secular publications which lasted for as short as a month or as long as 125 years (the Oregonian). The first owners and editors of the Sentinel were the Bavarianborn Henry Herman and the Englishman Joln Atkinson, both of whom could boast of considerable jourmalistic experience on daily papers in both San Francisco and Portland. 105 Though its editors were not Irish, the Sentinel from 
the start copied the content and flavor of Eastern journals like the Boston Pilot which had already made American Catholic journalism almost synonymous with the expression of Irish culture in the United States. 106 The sentinel in its first issue-announced its purpose in a confident tone befitting a publication which carried on its masthead the motto, "One God, One Faith, and one True Church":

It cannot be denied that prejudice is one of the chief weapons in the hands of those men who take every opportunity to preach against the Catholic Church, and we might truly say, the only one with which they are able to make any impression. To combat these prejudices and to give our fair play-loving [sic] and unbiased dissenting friends a true view of our faith and doctrines will be one of our principal objects. All we ask of the public is $f^{\circ}$ give us a fair hearing and an impartial judgment. 107

The Sentinel faithfully reported the local, national and international activities and the views of notables in the Church, but a majority of its space was always devoted to other matters. Prominent on the editorial page of the four-page newspaper (enlarged to eight pages in 1873) were its columns of foreign news from European nations with large Catholic populations, led by the numerous items from Ireland. Nothing that illuminated the injustice and brutality of English rule or the suffering of the consistently virtuous Gaelic masses was omitted by Herman and Atkinson. In a response to jibes by some Portlanders that the Irish were inherently prone towards criminal behavior, the Sentinel's editors published this "fact" in defense:

There aze counties in Ireland in which there is less crime of any sort than in any similar district through- 
out the world, and the more completely the population is Irish in the ethnological sense of the word, the lighter iss sure to be its shade upon the criminal
chart. 008

The Sentinel's primary purpose, however, was really not the coverage of news of interest to its Catholic and other readers. In practically every issue, the journal devoted the majority of its space to speeches and stories of moral import and spiritual rectitude. Appeals to parish members to send their sons and daughters only to Catholic schools and to read solely newspapers and books approved by the church were mixed with fictional serials with titles like "Oona Moriarity: An Incident of Irish Peasant Life". This was a tale of a young woman from the West of Ireland who marries a boring bat hard-working man after her adventurous but unfaithful lover is killed in 3 storm at sea. 109

The editors sternly advised their readers to be on guard against a slippage in their faith or absolute adherence to the dictates of the Church. The "evils" of the secular education promulgated in the Portland public system of "common schools" came in for repeated attacks, including this warning to parish parents:

Let every Catholic parent beware that he neglect not his auty in the christian education of his children, lest in his old age they be to him a curse, instead of a blessing, and to theiffcountry a shame and to their zeligion a scandal.

clearly, residence on the frontier had not allayed the fears of Catholic immigrants for the disappearance of their spiritual cuiture. 
A topic of frequent concern in the pages of the Sentinel by 1873 was that of temperance. With Irish saloon-keepers among the leaders of prominent organizations like the Hibernian Society and the Emmet Guards, Herman (who became sole owner and editor in 1872) and his successor in 1874, Stephan McCormick, might have thought it prudent to relegate their stand against alcohol to moderate comments in the back of the paper. But "the curse of drink" was too great a problem not to be combatted directly. Outside the parish community, every Protestant minister in town and a number of determined midaleclass women reformers were blocking the entrances to bars on bustling Front street and pressuring the city council to raise saloon license fees higher than their owners would be able to pay. ${ }^{111}$ The sentinel took a strong stand against liquor but, as the voice of the Church of many drinking men, it opposed the tactics of its Protestant counterparts in favor of a more salutary solution.

McCormick wrote in March, 1874, that he abhorred the recent "spasmodic crusades" of "preaching women and crowing hens" 112 and pointed to the Father Matthew Total Abstinence and Benevolent Society as an alternative. The Society had been incorporated two years earlier as a chapter of the international organization begun in the 1840's by the Irish priest, Father Theobald Matthew. The Gaelic priest toured the United States in 1849 and 1850, winning thousands of converts to his method of "total abstinence", in which drinkers met in mass gatherings to take a solemn pledge to never again 
touch alcohol. 113

The Sentinel followed the progress of its local society closely, reporting by the summer of 1874, that many catholics had "taken the pledge" and that over 100 of them were taking part in the activities of the organization. 114 McCormick himself was a member of the group and was often called on to use his prodigious rhetorical skills to recount the story of Father Matthew's exemplary life of piety and service. 115

The views of the Catholic Sentinel towards the temperance issue were one indication that parish leaders were profoundly worried that an atmosphere of corruption in the world was endangering the moral health of the overwhelmingly immigrant Portland laity. An 1871 editorial entitled, "The Degeneracy of the Present Age", declared, "The much-lauded and progressive age in which we live may be an age of human knowledge and science, but none can deny that it is, in a great degree, also an age of utter depravity, infidelity, anò crime."116 A year later, Father John Fierens, the Belgianborn pastor of the parish church, stated his anti-modernist opinions in unequivocal terms:

Immorality flows wide-spread over the land -- it has uprocted all sense of christian precepts; internal instincts are blunted and destroyed; parental obligations ignored; conjugal relations abrograted; a false philosophy has been implanted, and the education we set so much store in, is used as aly instrument to foster crime and encourage vice.

The greatest fear of these men was that the "wickedness" of the frontier city would irrevocably destroy the nature of $\mathrm{Ca}-$ 
tholic family life which they saw as the strongest kulwark against absorption into a growing whirlwind of evangelical Protestantism, socialism, and the eventual destruction of ordered civilization. 118

The Irish couples married in the Church of the Imraculate Conception from 1860 to 1870 continued the demographic tendencies of the much smaller group that was wed in the 50's. 119 The average age of both partners remained high: 29.3 years for the men; 26.2 for the women. However the growing number of native-born men and women of Irish parentage had begur to shift the totals downward. Second-generation Irish women in this period averaged only 20.7 years at their marriages; while their male counterparts had an average age of 27 years. In comparison, Irish-born men and women were wed at the higher ages of 32.4 and 27.6 years, respectively.

One feature of Irish church weddings in Portland that distinguished them from Eastern urbar patterns was the large number of Irish-born women who married non-Irish men. 120 one out of every five marriages in the sample (from 1852 to 1876) was of this type; whereas only $6.7 \%$ of the weddings were of Irish men to native-born women. There seems to be no clear explanation for this phenomenon. Non-Irish men were, on the whole, in better financial condition than immigrants; but this was, if anything, more true in cities iike Boston and New York where far fewer Irish women married outside their national circle.

Perhaps the same laxity of traditional standards of Cath- 
olic conduct that Father Fierens and the editors of the Sentinel inveighed so vehemently against was partly responsible for so many atypical marital choices. The fact that most of their non-Irish husbands were Catholics of either German or English birth ${ }^{121}$ helps to dim the importance of the phenomenon somewhat. Portland's Catholic population was a heterogenous group, which, though led by Irish immigrants, was remarkably free of hostile rivalries within its ranks.

By 1870, enough children had been born in Portland to Irish couples to be able to speak of the particular characteristics of this first generation of immigrant offspring in the Pacific Northwest. To begin with, a more stable urban environment decreased the rate of infant and child mortality. of 184 boys and girls in the sample (of marriages from 186070), only 8.18 of them died before reaching the age of six. The contrast with the almost $18 \%$ who succumbed in the previcus group (see above, p. 31 ) is striking. In addition, schoolgoing had become a regular practice for the majority of parish children. Of the 33 children of school age (6 to 15) in 1870 , over 788 of them attended classes often enough to be listed as students in the census schedule or in the St. Mary's pupil register. 122

For Irish mothers, childbearing, as for other women throughout the nineteenth century, was almost a continual occupation, especially in the first decade of marriage. There are few instances of women married in the church before the age of forty who did not give birth at intervals of roughly 
two years. Childless Irish women were as much a rarity in Portland in 1870 as Conrad Arensberg found them to be sixty years later in County clare, when he recorded one childless woman's impression of her rural community's attitude towards such "unfortunates" as herself:

No matter how much money you have, no matter how goodlooking you are, if you don't have children, you are no good. But if you are ugly as the worst and have children, you are all right. 123

The rate at which Irish couples who married in the 1860's left Multnomah County less than two decades later was even greater than that for the smaller group of the 1850's (see above, p. 20). By 1880 , only $44.1 \%$ of the 93 Irish couples in the sample who were married in Portland in the 60's were included (either together or separately) in the census schedules for the entire county. By this time, avenues of escape from north-central oregon were vastly more numerous than they had been twenty years earlier. Nevertheless, Portland's continuing character as a commercial city without a significant industrial base no doubt hampered its ability to keep many of the poorer and/or more footloose Irish families in town.

The economic lot of those who stayed improved steadily as Portland grew, but this did not change the occupational pattern which had developed soon after the first Famine-era imrigrants came to the settlement on the wiliamette. Irish men and their sons continued to make up a far larger percentage of the unskilled labor force than their overall numbers would indicate. In 1870, Irish-born laborers comprisec 
$31 \%$ of the total laborers (46\% in 1860), dipping to $26 \%$ ten years later. 124 Despite the influx of Chinese, who began to move into Portland in the 60's and were a tenth of the city's population by 1890 , the trades of porter, stevedore, hostler, hackman, and the like continued to be dominated by men who spoke with a brogue.

The most significant economic movement of families with Irish-born husbands in the 1860's and 1870's was into mediumsize businesses and the professions. In 1865, for example, only 8.38 of Irish men married in the $60^{\prime} \mathrm{s}$ in Portland were working in jobs that could be classified as both skilled and non-manual. ${ }^{126}$ By 1880, their number had more than tripled to $26.7 \%$, an indication that some craftsmen and shopkeepers (54.2\% in 1865; down to $30 \%$ of the total fifteen years later) were riding the economic roller coaster to their own advantage. As early as 1871, the Catholic Sentinel could single out its Irish readers as particularly capable of financially encouraging immigration to the state, "We have many well-todo and prominent citizens of Irish birth and parentage . . who have both ability and means to do something for their fellow countrymen and co-religionists. . . "127

As Portland's economy grew in size and sophistication, the activities of Irish families shifted to meet its changing denands. A good example of this process is the large family of Canadian-born James Freeman and his̆ Irish wife, Bridget Keefe. When they were married in August of 1860 , James at 31 years of age, was a teamster who worked for a small warehouse 
on the northwestern edge of town. All we know of Bridget is that she was 17 on her wedding day and that she had been born somewhere in Ireland two years before the onset of the Great Hunger. Over the next twenty years, Bridget Freeman gave birth to eight children, seven of whom lived past their infancy. Lacking any specialized skills, James was doomed to working as a laborer for several sawmills in the northwest corner of the city where he lived. The city Directories of those years alternately list Freeman as a laborer (1864), a sawyer (1868), a laborer again (1870), and a planer (1873-1875). By 1876, he appears to have improved his standing and wages a bit; since the Directory notes he has become a carpenter. However, the next year he is back to his former planer's job at the sawmill owned by the Nicolai brothers.

All seven Freeman children began school as soon as they reached the age of six and the eldest sor, James, Jr., was listed as a "farmer" by the 1880 census, though, for some reason, he still lived at home with his parents and younger siblings. There are no details in the historical record to enrich the story of the Freeman family; their lives revolved around oregon's major industry and they found enough to keep them in Portland for two decades in which its population increased by over $2000 \%$.

Other families of laboring Irish participated more actively in the affairs of their parish church and national group. Timothy and Johanna Brandon were both 31 years old at their marriage in 1865. Living close to the center of town 
at 12 th and Jefferson Streets, Timothy, who held low-paying jobs as a laborer and a drayman, was elected to high offices in both the local Hibernian Benevolent and the Father Matthew Total Abstinence Society throughout the 70's. Whether there was friction between Timothy Brandon and the saloon-owners and hara drinkers who often led the Hibernian Society or whether his position as Marshal of the Total Abstinence group was insincere is unknown. Brandon, however, was a native of the County Kerry in the southwestern reaches of Ireland, and he was probably not one to let differences of opinion over liquor interfere with good fellowship. Johanna Brandon, born in the neighboring West Ireland county of clare, entered her two daughters (born in 1866 and 1869) in St. Mary's when they were but five years old. Despite their family's poverty, both girls stayed in the convent school until they were well into their teens. Like most Irish women in Portland, Johanna Brandor evidently never worked outside her home.

The sight of married protestant women working in offices, teaching school, and staging demonstrations in front of saloons contrasted sharply with the lives led by all but a few Irish Catholic women in Portland in the 1860's and $70^{\prime} \mathrm{s}$. In 1870, only 26 of 296 Irish women over the age of fifteen in the city worked in any other field besides domestic Iabor. Ten years later, the percentage was a little higher with 56 of the 419 Irish immigrants employed outside their homes and not in anyone else's residence. 128

Once they were married, Irish women of all classes werc 
confined to doing housework and to bringing up their children. Unlike their husbands, they had almost no outlets outside the family for their intellectual or emotional energies. In the small minority of Irish households in which one or more of the adult kin of a spouse live $(6.98 \text { in } 1880)^{129}$ this isolation may have been somewhat eased, but the apparent stability of Irish marriages remained a matter j.n which the wife invested totally because she had no other alternative.

An ideological defense of the circumscribed roles of Irish Catholic women was trumpeted frequently by the Catholic Sentinel, whose editors saw the small but well-publicized woman's suffrage movement of the time as a pathological indication of the true nature of Protestant reform activities. In its lead editorial in a May, 1870 issue, the sentinel vented its anti-feminist beliefs:

It seems that this new-fangled idea of 'woman's rights' has found its way from the far East to our new West, where, we were in hopes, so few of the strong-minded could be found that they would not dare to put in their ridiculous and foolish claim of being enfranchised, or in other words, of being unsexed. . . We are glad enough to chronicle the fact that no Catholic woman has as yet sullied her womanhood by taking part in this unwomanly and withal unchristian agitation, and express a hope and abiding faith in the strength of the salutary doctrines which the Church impresses upon her daughters in regard to the duties of Christian women, to save them from the contaminating influence of this malady. 130

The image of wumanhood that the Sentinel's writers sought to uphold stressed attributes like tenderness, sympathy, and devotion; a woman's great value lay in her ability to support the afflicted and the suffering rather than to ag- 
gressively seek "unnatural" rights for herself. ${ }^{131}$ The piety of the "noble Irish working girl" came in for special commendation: "She - . understands her religion, if she may not be able to defend it with the eloquence of a theologian, she will illustrate it with the virtues of a saint."132

Irish women had, of course, no way to state their opinions on such questions. The best known feminist in Portland, Abigail Scott Duniway, who published a weekly paper from 1871 to 1887 called The New Northwest, often criticized the views and actions of the Catholic Church and the Irishsupported Democratic Party in her periodical. Commenting on the refusal of Roman authorities to legally recognize the suspected daughter of an influential Cardinal, Duniway, in terms not calculated to win the heart of a devout Irish woman, queried accusingly, "How long will the advancing civilization of the world support a church whose immoral, unjust and bigoted tenets permit and whose decrees endorse such a foul crime?" 133

However, if their loyalty to husbands, religion, and traditional culture prevented them from siding with the views of the suffragists, some Irish women in Portland did express a decided ambivalence to assuming their expected place in life. At her graduation from St. Mary's in 1870, valedictorian Hattie Gleason, soon to be married to a man who was an accountant and an active member of Irish fraternal associations, discussed the road before her:

vacation, so dear to every pupil, and which soundside- 
lightful to the ears of the infant, to youth, and even to toiling man and ripe scholar, seems to have lost its charm to the girl verging on womanhood, who is about to bid adieu to her schoolday joys. Her vacation is not what it used to be, a respite from labor, amidst the pleasures of home and the family circle, but a step further in her life and a grade higher in woman's duty.134

The fact that the transition from a female community of comparative freedom to a life of housework and childrearing went publicly unquestioned by most second-generation Irish women like Hattie Gleason does not mean that her lyrical lament was not shared by her sister graduates. With only isolated evidence of what women thought about their own lives in 19th century Portland, this and other crucial questions cannot yet be truthfully evaluated. 135 
CHAPTER V

\section{PORTLAND'S IRISH: A LOSS OF POWER}

". - Our Irish mothers are the noblest of women. They may not know how to waltz or speak French or be up to the times, but they are honest, industrious, and religious, and the virtue of their lives is a school for their children. . As to Irish fathers; they excel in industry, honesty, and devotion to their faith. Their poverty is no crime, nor is it a disgrace."

-- Catholic Sentinel, December 2, 1875 (p. 3)

After the mid-1870's, Portland's Irish population began to diminish as a vital element in the social existence of the city. In part, demographic factors were the reason for this decline. Though immigrants from the impoverished rural districts of Ireland continued to arrive throughout the $19 t \mathrm{t}$ century, the passing of the Famine-era onslaught and its replacement by an even larger influx of people from Eastern ana Southern Europe meant relatively far fewer Irish were available as settlers in the Pacific Northwest. By 1890, the Irishborn population of Portland was only twice that of twenty years earlier $(1,638$ from 787$)$; while the city's numbers in that time had increased by practically five times to 46,385 from 9,565. The Irish share of the town's foreign-born contingent decreased proportional1y, from $30.5 \%$ in 1870 to only $9.5 \frac{8}{3}$ in 1890.136

Moreover, the growing complexity of Portland's ethnic 
compositicn made the pioneering community associations of the Catholic Irish less unique and less significant in civic affairs. By 1880, every immigrant group of more than a hundred members could boast of at least one benevolent organization of its own. There were several large and active German groups, including the St. Joseph's German Catholic Society of which Henry Herman was a founding member; both a British and a Scottish benevolent society; a Scandinavian association; two Jewish groups; and the Union Laborieuse, the center of French and French-Canadian workingman's activities. 137

One indication of the declining strength of the Portland Irish appeared in the program for the city's gala centennial celebration on July 4, 1876. Of the 77 "notable" men who were named officers for the event, only two of them -- the indefatigable editor, Stephen McCormick and city councillor Joseph wiley, were of Irish descent. Though Irish sponsorship had been instrumental in the building of Portland's first hospital the year before (St. Vincent's), native-born businessmen and politicians afforded them only token representation in what was the biggest public event in the city's history. ${ }^{138}$

The growth of a Catholic community in East Portland may have further eroded the base of the larger parish on the western bank of the Willamette. In the fall of 1876, Archbishop Blanchet dedicated the Church of St. Francis of Assisi on 12th and $\mathrm{K}$ streets in East Portland and named a German priest, Louis Verhar, to be its pastor. Verhaag's parish included the entire stretch of east Multnomah County, stretching from the 
in the $1360-1870$ period. Since there was no real difference in the birthdates of those married in the earlier as opposed to the later period, it appears that the declining proportion of Irish Catholics in Portland was not matched by a drop in their preference for a marriage partner of their own religion or national background.

One feature of Irish consciousness in the 70's was a volatile serse of outrage at the growth of the city's Chinese population which seemed to threaten the jobs of Irish laborers and the Western European nature of Portland's cultural environment. Earl Pomeroy and other historians have noted that immigrants in general and the Irish in particular were in the forefront of anti-oriental agitation on the west coast in the 19th century. 141 In Portland, the Irish were a smaller proportion of the total population than they were in most coastal cities in Californial 142 and thus took the influx of the Chinese harder perhaps than even some of their southern brethren (whose nativism in this regard is better known). As early as 1870, when the Chinese colony in Portland was far smaller than the community of thousands that was present by the mid-1880's, the Catholie Sencinel editorialized that the oriental immigrants appeared ". . . to infest every part of the city . . ." and urged the sity's landlords to consciously "confine" these "human cattie" to one section of town. 143

: The nationwide depression which began in 1873 exacerbated the resentment of Irish laborers, many of them unemployed for long stcetches of time, against recent Chinese arrivals. 
small city where the church was located to the farming settlements along the Sandy River twenty miles to the east. 139 The new parish was decidedly less Irish in character than its neighbor; few Gaelic immigrants were farmers and the Germans in East Portland were more numerous, more prosperous, and more cohesive as a group than the sons and daughters of st. Patrick.

If the picture of Catholicism in the Portland area was losing its Irish tinge by 1880 , we would expect to find evidence of this in the marriage statistics of the church of the Immaculate Conception. An examination of the birtholaces of those married in the Church from 1870 till 1876 (when the operation of St. Francis begins to "compete" for marriages with the cathedral across the river) however shows that men and women of exclusively Irish background continued to dominate the nuptial celebrations. In this period, $61.1 \%$ of the marriages for which at least one partner's birthplace is known were between people who were either Irish-born or native-born of Irish parents. The only significant change from the marriages in the Church between 1860 and 1870 , in this regard is the understandable decrease in the number of marriages in which both partners were born in Ireland (from $46.2 \%$ in the first group to 29.68 in the second).

In addition, adherence to the Church's extreme distaste for intermarriage with Protestants increased in the later period. $^{140}$ only $7.4 \%$ of the marriages in this sample group were mixed ones as compared with $17.2 \%$ of the Irish marriages 
The belief was widespread that the Chinese were working for lower wages at jobs recently held by Irish and other white men. This rancor often extended to the ruling group of businessmen and big property owners who were almost exclusively Protestant in religion and Republican in politics.

The hatred was a mutual one. After a massive fire in Portland in August, 1873, in which a large section of the downtown district was destroyed, the editor of the staunchlyconservative and Protestant-run oregonian told a frightening story. During the fire, he reported having seen a member of the Emmet Guards -- the Irish militia organization -- force a Chinese man at the point of his sabre to run barefooted through the burning streets. 144 Coming after reports of similar abuses committed by members of the Emmets against chinese during a downtown fire a year earlier, 145 the editor's accusations were widely believed. The efforts of Joseph $R$. Wiley, on the part of the Irish community, to refute them were rather perfunctory. 146

Both the economic downturn and the increase in Portland's Chinese population continued throughout the 70's. Resentment against the allegedly immoral joss-houses and theatres in Chinatown led the City Council by 1879 to condemn the "filthy and indecent practices and habits" of the Orientals and to, in turn, castigate the "rich companies" who, it was charged,". . own not only the labor of the men but the bodies of the women."147 Though one student of Portland workers in this period claims that the Chinese worked in oc- 
cupations that did not compete with Irish men, 148 the ten-fold growth of the Chinese community to 4,539 in 1890 so clearly inflamed the racial animosity of the Irish of all classes in the city that objective economic estimates made a century later are almost beside the point. Hostility expressed by one group of insecure immigrants and their children toward a newer group with a radically different culture and physical appearance has recurred throughout American history and defies explanations that do not take the psychological stresses of frustrated aspirations into account.

If the morality of the inhabitants of Chinatown was a burning issue among the Portland Irish in the $1870^{\prime} \mathrm{s}$, the errant behavior of some of their own children was even more disturbing to them. Portland's character as a "wide-open" town of transient laborers and miners was a fertile seedbed for gangs of young Irish boys who were probably smaller replicas of the Fly Boys, Plug Uglies, and Buckaroos which flourished in the immigrant neighborhoods of Eastern cities after 1830.149 In 1871, the ever-vigilant Sentinel reported that five Irish boys under 12 had been caught stealing mink skins from one furrier in town and selling them to another. The blame for this type of action, the Sentinel implied, rested on the parents of such children:

Why is it that numbers of boys, from the ages of six to eighteen, roam the streets of this city day and night, with no other purpose apparently than to do mischief, is beyond our conjecture. They are surely not all orphans or outcasts, without parents or a home. . What a terrible account these neglectful parents wiil have to settle with the great Judge of Mankind! 150 
In the face of a social situation which threatened the steady discipline of orderly family life, the Sentinel flailed out at the cultural artifacts of the cosmopolitan and Protestant culture. Stephen McCormick editorialized flatly, in 1874, "To the corrupt literature of the day may be traced much of the defection that exists among Catholic youth"., 151 and went on in future issues to condemn everything from crime reports in daily papers to popular dancing as "preparing the way" for the eventual "damnation" of a large segment of the younger generation. 152

In its fruitless attempts to plug the dam of depravity, the Sentinel and the church officials it echoed were really attempting to block the complete triumph of what they saw as a corrupt modern age that had begur with the Reformation. In the 1870's this spirit was being promoted in their eyes by a broad cabal of labor organizers, Methodist ministers, Republican editors, and middle-class feminists. The "One True Church" seemed to be both under frontal attack from its ideological enemies and weakened from within by the growing indifference of young Catholics.

McCormick and his associates saw Catholic education as the main bulwark against their children's loss of faith. Yet even in this sphere, their aims were subtiy undermined by the demands of industrial society. At St. Mary's Academy, for example, the curriculum was remarkably similar to that prevailing at the competing public schoois. Both emphasized the learning of basic subjects like reading, writing, spelling, 
arithmetic, natural science, and American history. Perhaps because of the large number of non-Catholic students at the school, religious education at St. Mary's was restricted to a few optional courses in catechism and Bible history. The formal and authoritarian nature of instruction at St. Mary's was duplicated in Portland's public schools in the late 19 th century. These were so strictly regulated that they were constantly criticized for an adherence to myriad rules governing all activities from the duties of students in regard to exams and absences to the precise times during the day when windows could be open in classrooms. 153

Though its more articulate sponsors lauded the devotional ideals supposedly inculcated at St. Mary's, the Catholic girls who attended the school had to prepare themselves for the same secular tasks as their Protestant and Jewish counterparts. Thus the learning of social graces like etiquette, drawing, and piano-playing were popular studies at the Academy. Furthermore, by the mid-1880's, students in the higher grades were also taking "business courses" to fit them for employment in the offices of the financial and colmercial corporations burgeoning in the Pacific Northwest. In 1892, the administration of St. Mary's de-emphasized the sectarian nature of the school's orientation in stating its overall objectives:

. . the object of this institution. . . being to impart to young ladies a Christian education, solid, useful and cultured; in a word, to teach them all that
is taught in the most approved schools [italics mine]

When Stephan MoCormick bemoaned the lack of Irish pride 
among young students in an 1875 editorial, he could easily have been referring directly to the effects of the same st. Mary's education he had so often urged Catholic parents to support :

They heard the religion and nationality of their parents spoken lightly of as a natural consequence, and because of a desire to be up to the times and be like unto others, these children were driven to lamenting their unhappy condition and to mourning over the decrees of relentless fate that made thern only Irish: - . The old folks had to get a lesson. They gave the sound of a $A$ to $E$, and oh how flat they spoke and how un-American were their actions and general deportment! Dear, how could these elegant young ladies -- studying music while their mothers washed to pay the tuition -- which indeed, is rothing to be ashamed of -- and these stylish young men, how could they bear the idea of their being mere Irish! -- their parents being untutored -- in the etiquette of the age and unacquainted with the rules of polished society? 155

The demographic shape of Portland's Irish families in 1880 reflects the waning identity upon which McCormick turned his satiric talents. Less than $30 \%$ of the marriages between people of Irish origins in the Church of the Immaculate Conception between 1870 and 1876 were unions of two immigrants. The consequent rise in the numbers of native-born children of Irish parents being wed in the Church was marked by a startling dip in the average age at which second-generation Irish women were getting married. In the first six years of the decade, these women became wives at the average age of 16.3 years.

When contrasted with the continued late age at marriage of Irish-born women (29.9 years in the same period), the effects of life in the west on this crucial facet of family his- 
tory becomes apparent. Second-generation Irish women had less of a traditional economic role than did their mothers, and the pressure on them from their non-Irish peers was, for that reason, probably harder to resist. At any rate, many daughters of immigrants in Portland got married as soon as they finished school or, in some cases, in the middle of their education. Native-born sons of Irish parents, faced with the responsibility of learning a trade or at least establishing a steady source of income, upheld a relatively late age of 29.3 years at marriage.

Marriage among Irish Catholics in Portland in the late 19 th century was not always the permanent arrangement that their religion and culture prescribed. Divorces of course were expressly prohibited, but the death of one of the partners within a few years after marriage was not uncommon. Of all women of Irish birth or Irish parents born in the parish church between 1870 and 1876, fully one-sixth of them were widows. ${ }^{156}$ A small number of women were married three times in the space of less than twenty years. We have no method of speculating on the psychological effects of multiple sexual relationships on people of puritanical mores or on the tenor of a housenold filled with children from two or more marriages. However, the dominant picture of stable nuclear families among the Portland Irish of a century ago is certainly not a unified one.

The economic fortunes of the Irish families formed in the first half of the $1870^{\prime}$ 's were not markedly better or worse than 
those of their predecessors in the city by the willamette. Several Irishmen who had been unskilled workers at their marriages became owners of small businesses by 1880. The only laborers in this group were immigrants from Eire; the nativeborn had been able to acquire at least a semi-skilled position as a teamster or the like. Perhaps the increase in the proportion of families taking in boarders in the 70's (see p. 33) held the Irish back from dramatic economic advances. The long depression in the middle of the decade, however, was probably a more significant factor. Most Irish families continued to have fewer than four children at home and no boarders, ${ }^{157}$ rendering household structure of minor importance in gauging the reasons for the stagnancy of occupational mobility among the Hibernian community.

One example of this horizontal movement of Irish families in the social structure was the household of James J. and Mary M. Murphy, who were married in February, 1871. Both part-ners were native-born children of Irish immigrants and were married at the ages of 30 and 22 respectively. James Murphy was an officer of both the Catholic Library and Christian Doctrine Society and the Hibernian Benevolent Society in the 70's and early 80's; though his occupation as a grocery delivery-clerk put him near the bottom of the ladder in occupational status. Till his marriage, James had boarded with publisher and Sentinel editor Henry Hërman; but this does not seem to have helped him to a better paying job. Three sons were born to the Murphys from 1872 to 1879 , adding 
financial burdens to an already insecure family budget.

The families of laborers in Portland were not, as a

rule; any larger than those of saloon-keepers or lawyers, but even a moderate number of children could make it more difficult to escape the cycle of poverty. When the Irish immigrants, James Maloney and Bridget Stackpool, were wed in June, 1874, Bridget brought her three sons from an earlier marriage into the couple's small house on the northwestern edge of the city. At 37, she was three years older than her new husband. James Maloney, like many Irish-born men in Portland at the time, tried his hand at several unskilled jobs throughout the $70^{\prime} \mathrm{s}$, from miscellaneous tasks at a nearby sawmill to sailing on the boats that plied the route from Portland to San Francisco to mining for base and orecious metals in Eastern oregon and Idaho. The Maloneys had no children of their own in their first six years of marriage, but were able to send Bridget's two youngest boys to school. Though the large majority of Irish women at the time worked solely on their own housework (with, perhaps a little outside laundry if time permitted), a few found themselves in circumstances where they were forced, whether willingly or not, to depend exclusively on their own labor-power for survival. Anne Fitzpatrick emigrated alone from Ireland as a young girl. in the mid-1850's and began to make dresses in Portland fifteen years later. Even after she married James Armstrong, a second-generation Irish laborer, in 1875, and had three children in the space of four years, Anne con- 
tinued her dress-making business at home. Hannah Murphy, a native of County Cork, was widowed by her first husband in Portland after less than three years of marriage, and did not remarry until 1875, ten years later. In the interim, she opened her house to boarders, making enough money to send her young daughter to St. Mary's Academy. Her second husband, a ship-carpenter, was originally one of her boarders.

The gradual erosion of the separate existence of an Irish community in portland can be illustrated by the wedding of William J. Quirk and Wilhelmina Reinwald in March, 1876. Quirk, born in Ireland in 1850, was already a successful saloon-owner and an officer in the Hibernian Society. His marriage to a 16-year-old native-born woman of German-Protestant parents would have been unique ten years earlier, but by the late $70^{\prime} \mathrm{s}$, intermarriage no longer spelled a virtual break from one's associates. In rural Morrow County, Oregon at the same time, according to one report, many Irish men returned to their native land to find wives, and most others, "lived very monastic lives and a tragically large percentage of those who remained in America, lived and died bachelors." 158 The more equal ratio of men and women in Portland (about 3 to 2 as compared with 7 to 1 in Morrow County) and the more exciting life offered in an urban environment both acted to limit the return rate of young Irishmen to an insignificant trickle. By the time the transcontinentai railroad was connected to Portland in 1883, the city of 25,000 people was at its zenith as the economic center of the entire Pacific Northwest. 
In the next decade, the competition of seattle in the Puget Sound area to the north would diminish Portland's supremacy, but in the mid-80's, the Oregon city was the hub of trade and of what manufacturing existed in the vastly underpopulated region. 159 Irish immigrants and their children had become ensconced in the lower reaches of Portland's society; although families who remained in the city for more than a decade could expect to experience a moderate degree of economic mobility.

Despite the fact that men of Irish descent headed the police force, edited a weekly newspaper, and even were elected to the U.S. Senate by the state legislature (James K. Kelly, who served from 1870 to 1876), the aspirations of most Irishmen and their male children could realistically stretch to encompass only the ownership of a small business like a saloon or a bootery. Women of Irish background could hope only to marry above their class; or else to clean, cook, and nurture a family only slightly less poor than the one into which they had been born. 
CHAPTER VI

\section{CONCLUSION: THE FAMILY AND ETHNIC SURVIVAL}

The Irish families that were formed in Portland, Oregon, in the quarter-century after the establishment of the city were the product of an ancestral society near collapse and a young region beginning to form its cultural parameters. The characteristic pattern of 19 th century rural Ireland marked by late marriages, close kinship relations, and the function of the peasant family as a self-contained economic unit was largely destroyed in the western city. On the other hand, the exigencies of working for a wage or running a small business in a totally unstable system of production demanded that the family unit itself be kept strong as the inviolate base from which immigrants and their offspring attempted to achieve prosperity or at least survival.

In this arena, one's identity as an Irishman or woman reaped emotional rewards but became less and less functional in a city in which every non-Indian was, in a sense, an immigrant. Portland never had a Celtic community like that of Philadelphia where, "The parish and school network became sufficiently comprehensive that the individual could proceed from cradle to career without substantial non-Catholic contact." 160 There was also no geographically defined Irish neighborhood in Portland; laboring families of all national- 
ities tended to cluster on the outer fringes of the continaily expanding city, walking to their jobs located either nearby or downtown.

As in other cities with substantial numbers of Irish immigrants, the associational life of the Portland Irish was centered around their parish church. Secular organizations like the Hibernian Benevolent Society and the Ancient order of Hibernians were active in generating support for church needs and the observance of religious ceremonies; while the clergy and the Sentinel praised the good work of the organizations and publicized their activities regularly. Other groups like the Catholic Library and Christian Doctrine Society and the Father Matthew Total Abstinence Society were formally adjuncts of the church; participation in them was viewed as performing a moral duty as well as enjoying the company of one's friends.

The vigor and enthusiasm that marked the intersecting community of Irish and Catholics in the 1860's and 70's was short-lived. The aging of the generation of Famine immigrants and the relative decline in the numbers of Irish in Portland from 1870 on were significant in causing this, but the constant turnover of the city's population might have doomed the separate culture of even a much larger group of immigrants. If we assume that families begun with a church wedding were the most residentially stable segment of the Irish community, then the exodus of over half of these families from Portland less than fifteen years after their formation explains some 
of the Sentinel's hysteria about the loss of visible Irish allegiance. People who are always ready to move for a more favorable job or for other reasons could not be counted on to raise money towards the building of a new cathedral or to help the landless exploited of county Kerry.

The difficulties and expenses of two voyages of 3000 miles each were hardly conducive to the retention of extended families. It is remarkable that so many Irish mothers, brothers, uncles, and sisters did live with their married relatives in Portland. As the city became more settled and transportation to the West more routine in the $70^{\prime} \mathrm{s}$ and $80^{\prime} \mathrm{s}$, the percentages of $\mathrm{kin}$ and boarders in Irish households increased.161 The comparative prosperity of those Irish who made Portland their permanent home no doubt encouraged their relatives and co-nationals to join them. Compared with the wretched poverty of London's or Boston's Irish slums in the same period, 162 the oregon city provided at least modest opportunities for people who could get there.

The Irish families of late nineteenth-century Portland accomplished the tasks that were necessary to the maintenance of an ordered though severely restricted existence. A thriving Church was established, most children knew school as a routine at a time when many of their relatives in the East and in Ireland were at work, and women were dissuaded from overtly challenging their preordained place in the social structure. By 1850, most of the commercially and culturally active women and men of Irish descent in Portland had been born after 
the onslaught of the Great Hunger of the late $40^{\prime} \mathrm{s}$. Though they did not experience the horrors of famine or the full virulence of nativism, the second generation did attempt to preserve the core of the peasant tradition of piety and discipline in their daily lives. 


\section{FOOTNOTES}

1. Aries' in Centuries of Childhood: A Social History of Family Life. New York: Vintage Books, 1964 (originaliy published in French in 1960), concentrates on the families of the French nobility from the 13th to the 18th centuries. He concludes that the meaning of the stages of life changed radically in this period, rendering childhood a period of separation from adult life and thus, paving the way for the emotionally charged nuclear family of the modern era. Aries' findings were so well-buttressed by data and so provocative that they inspired a complete re-examination of the reigning assumptions in the sclerotic field of family. history. For evaluations of Aries' work by two historians writhing from interdisciplinary perspectives, see Tamara Hareven's essay in The Family in History: Interdisciplinary Essays. Edited by Theodore $K$. Rabb and Robert I. Rotberg. New York: Harper Torchbooks, 1971; and David Hunt's Parents and Children in History: The Psychology of Family Life in Early Modern France. New York: Basic Books, 1970.

2. Stephan Thernstrom. Poverty and Progress. Cambridge: Harvard University Press, $1 \overline{964 .}$

3. Philip J. Greven, Jr. Four Generations: Population, Land, and Family in Colonial Andover, Massachusetts. Ithaca, New York: Cornell University Press, $19 \overline{70 .}$

4. Daniel J. Walkowitz. "Working-Class Women in the Giläed Age: Factory, Community, and Family Life Among Cohoes, New York, Cotton Workers". Journal of Social History, V. 4 (Summer, 1972); p. 464-490.

5. The only two studies I know of that concentrate on the relationship between immigrant families and the social environment are both concerned with Eastern urban areas: Virginia McLaughlin's work on Italians in Buffalo, "WorkingClass Inmigrant Families: First Generation Italians in Buffalo, New York." Unpublished paper delivered before the annual meeting of the organization of American Historians, April, 1971; and Tamara Hareven's unpublished work on French Canadians, Poles, and Greeks in the textile town of Manchester, New Hampshire.

6. The major works axe Carl Wittke. The Irish in America. Baton Rouge, Louisiana: Louisiana State University Press, 1956; William V. Shannon. The American Irish. New York: The Macmillan Compary, 1963; George W. Potter. To the Golden 
Door: The Story of the Irish in Ireland and America. BosEon: Little, Brown, and Co., $\overline{19} 6 \overline{0 ;}$ Oscar Handlin. Boston's Immigrants. New York: Atheneum, 1969 (originally published in 1941); and Dennis Clark. The Irish in Philadelphia: Ten Generations of Urban Experience. Philadelphia: Temple University Press, 1973 .

7. Among the English demographers who pioneered this method in the field of social history are Peter Laslett and the other members of the Cambridge Group for the History of Population and Social structure. A useful though rather technical essay on the technique with specific reference to Church of England parish records is E. A. Wrigley. "Family Reconstitution", in An Introduction to English Historical Demography. Edited by E. A. Wrigley. New York: Basic Books, 1966 .

8. Quoted in Edward H. Saveth, "The Problem of American Family History". American Quarterly, XXI, 2, part 2 (Summer, 1969), p. 337. Bailyn's use of a male pronoun to refer to historians of both sexes is unfortunate.

9. Fotter, To the Golden Door, P. 89.

10. Wittke, The Irish in America, P. 208.

11. See note \#6. Potter's work only covers the history of Irish in the U.S. up to 1850; the other two books take the narrative up to the post-1945 period.

12. Andrew M. Greeley. That Most Distressful Nation: The Taming of the American Irish. Chicago: Quadrangle Books, 1972, p. $180-181$.

13. See note \#6.

14. The special character of the "Famine Generation" is discussed in Chapter Three, below.

15. Handlin. Boston's Immigrants, p. 125-127.

16. Handin titles his last chapter on the period from 1865 to 1880, "An Appearance of Stability"; while clark sees the immigrants of the $1840^{\prime} \mathrm{s}$ and $1850^{\prime} \mathrm{s}$ as, "the survivors of a conquest that eradicated much of their indigenous culture", and thus more easily adjusted to dominant norms of attitude and behavior ( $p .91$ and passim).

17. See Clark, p. 26, and Handlin, p. 128-131, for examples. 18. Handlin, p. 177 .

19. Clark, p. 128 . 
20. Conrad M. Arensberg and Solon T. Kimball. Family and Community in Ireland. Cambridge: Harvard University Press, 1968 (first published in 1940); Conrad M. Arensberg. The Irish Countryman: An Anthropological Study. New York: The MacMillan Co., 1937. The jointly written volume is a monograph in the traditional style; while the latter is a series of lectures that Arensberg gave in Boston in 1936.

21. Arensberg, p. 184-216.

22. Ibid, p. 53 .

23. Arensberg and Kimball, p. 56-64.

24. Arensberg, p. 79.

25. Arensberg and Kimball, p. 201.

26. Arensberg, p. 79-102.

27. Messenger's work has been published in a book, Inis Beag: Isle of Ireland. New York: Holt, Rinehart and Winston, Inc., 1969 ; and in several articles of which the most accessible is, "Sex and Repression in an Irish Folk Community", an essay in Human Sexual Behavior. Edited by Donald S. Marshall and Robert C. Suggs. New York: Basic Books, 1971.

28. Messenger, "Sex and Repression in an Irish Folk Community", p. 20-21.

29. Quoted in Ibid, p. 12. I was unable to find Tracy's study of Irish personality, Mind You I've Said Nothing.

London: Methuen and Co., Ltd., 1953.

30. Ibid, p. 25.

31. Greeley, p. 104 .

32. Ibid, p. 106-107.

33. Tamara Hareven. "The History of the Family as an Interdisciplinary Field" (see note \#1), p. 212. Some of the best of the "new family historians" are John Demos, Philip Greven, Jr., Virginia McLaughlin, and Hareven herself.

34. There is an unpublished $\mathrm{PhD}$ dissertation which follow's the family of an Irish-born St. Louis businessman through several generations: Alice Lida Cochran. The Saga of an Irish Immigrant Family: The Descendants of John Mulanphy. St. Louis University, st. Louis, Mo., 1958. However the abstract of the study promises little to add to an understanding of Irish-American culture, "The fact that John Mullanphy was of Irish birth was of little or no importance on the frontier." 
35. Arthur W. Calhoun. A Social History of the American Family, Three volumes. New York: Barnes and Noble, 1945 (first published in 1917).

36. Calhoun, Vol. III, p. 321.

37. Ibid, p. 149. The writer's name was James D. Brian.

38. Drake, Warner, and others attempted to study the totality of life in urban communities like Newburyport, Massachusetts (five volumes beginning with The Social Life of a Modern Community with Paul.s. Lunt - New Haven: Yale University Press, 1941), the same city Stephan Thernstrom researched in an earlier period in Poverty and Progress, and the black ghetto of South Chicago (Drake and Horace Cayton. Black Metropolis. New York: Harcourt and Brace, 1945).

Thernstrom, a leading figure among contemporary socizl historians, has sharply criticized Warner's work for its ahistorical methodology. See, "Appendix: Further Reflections on the Yankee City series: the pitfalls of ahistorical social science", in Poverty and Progress.

39.

Thernstrom, Poverty and Progress; Herbert Gutman.

"The Reality of the Rags to Riches 'Myth': The Case of the Paterson, New Jersey, Locomotive, Iron and Machinery Manufacturers, 1830-1880", in Nineteenth-Century Cities. Edited by Stephan Thernstrom and Richara Sennett. New Haven: Yale University Press, 1969; Jackson Turner Main. The Social Structure of Revolutionary America. Princeton University Press, $196 \frac{1}{6}$ and many others.

40. Kenneth Lockridge. A New England Town: The First Hundred Years. Cambridge: Harvard University Press, 1969. Richard Eushman. From puritan to Yankee. New Haven: Yale University Press, 1968.

41. So far these have been mostly the work of colonial social historians. John Demos. A Little Commonweaith: Family Life in plymouth Colony. New York: Oxford University Press, 1970 and Philip J. Greven, Jr.'s Four Generations (see note \#3) are the best of these.

42. Daniel Feller. "Get a Job: Occupational Structure and Social Mobility in Portland, Oregon, 1860-1880". Unpublished Reed College B.A. Thesis, May, 1972, p. 7.

43. Herbert Gutman. "Work, Culture, and Society in Industrializing America, 1815-1919". American Fistorical Review, 78,3 (June, 1973), p. 560.

44. Potter, p. 532. The pilot was the most successful of all the Irish-American newspapers in the nineteenth century. 
45.

Ibid, p. 35 .

46. Potter estimates the total emigration from 1780 to 1845 at $1,750,000$ with another one million leaving from 1845 to 1855 (p. 35). The story of the prelude to the Famine has been told by many historians including cecil Woodham Smith. The Great Hunger. New York: Harper and Row, 1962; and the previously cited works by Potter, Shannon and wittke.

47. Greeley, p. 36-7.

48. Shannon, p. 23.

49. A well-written recent account is T'erry coleman. Going to America. Garden City, New York: Anchor Press, 1973.

50. Potter, p. 453.

51. Ibid, p. 148 .

52. This analysis is taken from a dated work but one that is still useful, especially for its statistical data on the social composition of the emigrant population: W. F. Adams. Ireland and the Irish Emigration to the New World from 1815 to the Famine. New York: MacMillan and Co., $1932, \frac{\text { especially }}{19}$ p. $\overline{192}-\overline{218}$.

53. Greeley, p. 44. Many young emigrants had been edu= cated for at least a few years in English-sponsored schools, and to make one's way to North America through the port of Liverpool, as most Irish did, required some knowledge of English. Gaelic-speaking habits of Irish in the U.S. survived, however, long past the Famine period as the credibility and great popularity of the dialect of $\mathrm{Mr}$. Dooley, Finley Peter Dunne's fictional Irish bartender and social pundit, demonstrated as late as the first decade of the twentieth century. A recent collection of Dunne!s most notable sketches is $\mathrm{Mr}$. Dooley on Ivrything and Ivrybody. New York: Dover Publications, Inc., 1963.

54.. Handlin, p. 151-177, provides a good survey of these organizations in Boston.

55.. Quoted in Potter, p. 537.

56. Shannon, p. 96; 86-94, passim.

57. Thomas Kerr. "An Irishman in the Gold Rush: The Journal of Thomas Kerr". Quarterly of the California Historical Society, VII, 3 (September, 1928), P. 205-229; VIII, passim.

58. Ibid, VII, P. 219 . 
Ibid, VII, p. 402 .

60 . Ibid, VIII, P. 169.

61. Though it might seem like a commonplace way for a man to speak of his wife, I think the usage is important. Ainy Kesselman, in a suggestive thesis about the diaries of women on the Oregon Trail ("Diaries and Reminiscences of Women on the Oregon Trail: A Study in Consciousness." Unpublished M.A. Thesis, Portland State University, 1974, p. 43.), remarks on marital relations from the female side:

- - women's relationships with their husbands were often quite formal. While women regarded their husbands as protectors and providers and sometimes as friends, they seemed to spend little informal time together and always referred to them as 'Mr.'

There is no record of Mrs. Kerr's actual feelings about her husband, but I feel the comparison is worth noting.

62. Kerr, VII, P. 206.

63. Edward F. O.'Meara. "Continue to Prosper: The History of the First Half Century of All Saint's Parish, Portland, Oregon". No publisher or date (but about 1971), p. 1.

64. Blanchet's ecclesiastical province included the entire Pacific Northwest, from Vancouver island to the southern border of Oregon and from the Pacific Ocean to the Rocky Mountains.

65. Paul G. Merriam. Portland, Oregon, 1840-1890: A Social and Economic History. Unpublished PhD dissertation, University Of Oregon, 1971, p. 185-193.

66. Rev. Willis L. Whalen. "The Pioneer Period of the Catholic Church in Portland, Oregon, 1851-1881". UnpubIished M.A. Thesis, University of Portland, 1950, p. 4-7.

67. Paul H. Douglass, et al. "The Portland Church Survey". Portland Council of Churches: Portland, 1945, p. 5.

68. One indication of this was the election of Irishman Hugh O'Bryant as Portland's first mayor in 1851: City Directory, $1863, \mathrm{p} .8$.

69. Arensberg, p. 96-7.

70. There were no Irish-born widows or widowers in this group to artificially tilt the averages higher.

71. Stephan Thernstrom. "Urbanization, Migration, and Social Mobility in Late Nineteenth-Century America". 
Towards a New Past, edited by Barton Bernstein. New York: Vintage Books, 1968 , p. 168.

72. Mary C. Wright. "The World of Women: Portland, Oregon, 1860-1880". Unpublished M.A. Thesis, Portland State University, 1973, p. 71 .

73. Merriam, p. 194-205.

74. Information in this and all succeeding histories of individual families were collected from the Parish Register of the Church of the Immaculate Conception, Portland, Oregon (1852-1880); Port land City Directory. Published and Edited by S. J. McCormick, Portland, Oregon (1863-1881); and the manuscript schedules of the federal censuses of 1850,1860 , 1870, and 1880. All these records can be found in the library of the Oregon Historical Society in Portland.

75. Burton.W. Onstine. Oregon Votes: 1858-1972. Portland: Oregon Historical Soceity, passim.

76. Wright, p. 59, 61 .

77. Ibid, p. 59, 61, 63. There was no significant difference between the household structures (nuclear, boarders, or kin) of all Irish families and those Irish families I studied closely, in which the couples were married in the local Catholic Church.

78. Merriam, p. 45.

79. Feller, p. 88.

80. Wright, p. 75.

81. Feller, p. 88.

82. Merriam, p. 222 .

83. Ibid, p. 243.

84. Ibid, p. 243.

85. City Directory, 1869, p. 7.

86. Merriam, p. 4c-45. Merriam notes, on page 44, that while the number of foreign-born in Portland's population increased from 1850 to 1890 , the three largest Western cities -- San Francisco, Sacramento, and Salt Lake City -- experienced a steady drop in their imrnigrant totals. The fact that the two largest cities in the Pacific Northwest after Portland -- Seattle and Astoria -.- also experienced increases in foreign-born residents during this period raises 
the possibility that the Northwest was more attractive to immigrants than the rest of the West, and that once having reached an urban area in Oregon or the Washington Territory (not a state until 1889), the foreign-born tended to remain in the region.

87. Charles A. Reynolds. "Portland Public Schools, 18451871". Oregon Historical Quarterly, 33 (December, 1932), p. 343 .

88. Information on the forming of St. Mary's comes from a completely laudatory but nevertheless useful book: The Gleanings of Fifty Years: The Sisters of the Holy Names of Jesus and Mary in the Northwest, 1859-1909. Portland: Glass and Prudhome co., 1909. A more modern version of the same history appears in a speech given by Sister Mary Margaret of St. Dominic, Superior, in October, 1963, to the Parents Club of St. Mary's Academy. Sister Anne Harold kindly furnished me with all the material on the history of the institution where she teaches and also functions as the school's historian.

89. Speech by Sister Mary Margaret, p. 8. This was the minimum fee. There were extra charges for meals, music lessons and supplies. However, the Sisters were extremely lenient toward poorer parents in this regard.

90. Catholic Sentinel, January 7, 1871, p. 3.

91. See, for example, Sentinel, July 2, 1970, p. 2, for a valedictory speech by Hattie Gleason. An analysis of the content of the education at St. Mary's is in Chapter Five, below.

92. Gleanings of Fifty Years, p. 116. St. Michael's also held adult classes beginning in 1873. It was located near the Cathedral at Third and Stark Streets which had replaced the original log cabin church in 1862.

93. Sentinel, January 14,1871, p. 3.

94. Gleanings of Fifty Years, P. 93-94.

95. The Fenians, with 40 members, were the largest of the young city's four volunteer military companies in 1866 (City Directory, 1866, F. 22). Except durjing fires, floods, and other disasters when they served the same purposes as their modern-day successor (the National Guard), the militia groups were largely fraternal and ceremonial organizations.

96. Whalen, p. 62 .

97. Information from City Directory, 1868 tinrough 1877, 
and Whalen, p. 61-75.

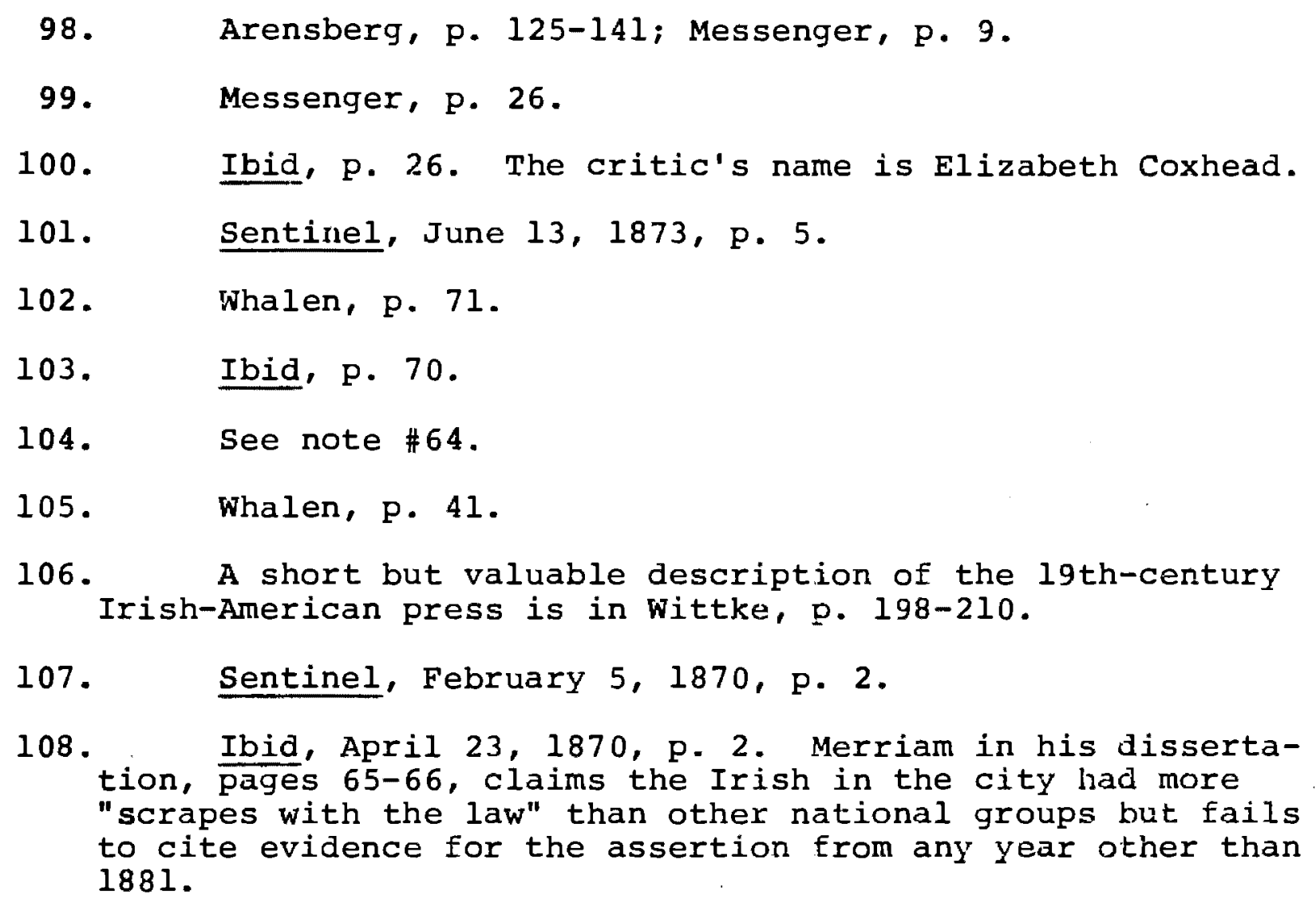

109. Sentine1, March $1,8,1873, \mathrm{p} .3$.

110. Ibid, December 7,1872, p. 1 .

111. Merriam, P. 137-138, describes the female-led temperance agitation of the early $70^{\prime} \mathrm{s}$ and the bitter class and ethnic antagonisms the dispute kindled between midale and upper-class native-born Protestants (who supported prohibition) and Irish and other immigrant workers (who defended their saloon-going habits). In the heat of the dispute, Oregonian editor Harvey scott referred to the anti-temperance forces as "rabble" and "the vicious and lawless classes" (Ibid, p. 138).

112. Sentinel, March 13, 1874, P. 4.

113. Dennis clark. The Irish ir Philadelphia, p. 103.

114. Sentinel, August 7,1874, p. 5 .

115. Ibid, October 10, 1873, p. 4.

116. Ibid, February 25, 1871, p. 2. 
117. Ibid, May 25, 1872, p. 1 .

118. See, for example, the Sentinel's attacks on the Paris Commune (May 27, 1871, p. 2); on radicals in the labor movement (June 22, 1872, p. 2); a reprint of an anti-Protestant article by Orestes Brownson (December 19, 1873, p. 1); and the statement that the Catholic Church is the only effective force against "Communism and Socialism" (September 12, 1879, p. 4).

119. There were 93 couples with at least one of the spouses identifiably Irish or of Irish parentage who were married in the 60's, compared with only 18 in the period from 1852 to 1860 .

120. Wright, p. 54, notes this national trend. According to her, immigrant women from 1860 to 1880 in Portland reversed the Irish pattern, intermarrying less with native men than male immigrants did with native women. Unexplained variables render this phenomenon hard to analyze. For example, how does one assign a "true nationality" to the large numbers of Canadians who lived and married in Portland but who culturally were all of recent European origins? Also Wright's figures on intermarriage are taken from the manuscript census schedules which do not record where couples were married. The tedious research of checking Portland civil and church marriage records for that period might turn up a different result.

121. Of 165 marrjages in the sample, 20 (12.18) were between Catholics and "non-Catholics" (one of the Church euphemisms for Protestants). In all but three of these mixed. marriages, the wife was the Catholic spouse.

122. I was unfortunately not able to find student records of the long-defunct St. Joseph's and St. Michael.'s schools.

123. Arensberg, p. 90.

124. Feller, p. 88 .

125. IEid, p. 60 .

126. Professions in this categcry included capitalist, speculator, high government official, bar-owner, editor, contractor, hotel proprietor, factory-owner, lawyer, brewer, doctor, and teacher. I am using a system of occupational status classification adapted from ștephan Thernstrom, Poverty and Progress, p. 90-96. This system, also utilized by Daniel Feller in his thesis, includes five categories (with the actual Portland occupations corresponding to them): manualunskilled (laborer, porter, stevedore, hostler); manualsemi-skilled (teamster, drayman, gardener, laundryman, log- 
ger, miner, railroađer without a specific craft); manualskilled (a skilled workman like a carpenter, a blacksmith, tailor, steamboatman, fisherman, expressman, farmer, industrial crafts like moulder, small businessman); nonmanual-semi-skilled (low government official, steward, accountant, night watchman, waiter, salesman); and the "top" category described above.

I had some difficulty placing men with professions like contractor (frequently a generic term for any.construction worker who could direct his fellows in a job) in one of the five categories, but on the whole I am confident that the results give a rough picture of changes in occupational mobility of Irish men in Portland from 1860-1880. Daniel Feller's thesis covers male workers in the aggregate in this period but is sketchy in regard to figures about Irish men.

127. Sentinel, April 22, 1871, p. 2.

128. Wright, p. 75, 77. The only jobs at which more than three Irish women were employed in 1870 were prostitute (6), seamstress (6), and "professional" -- a category including nuns -- (10). In 1880, only one Irish prostitute was reported, but there were 9 seamstresses, 5 professionals, and 13 female boarding house-keepers. Irish women, who had been "almost the only domestics in Portland in 1860" (Ibid, p. 78), were outnumbered two to one by native-born competition in 1870 .

129. Ibid, p. 63 .

130. Sentinel, May 14, 1870, p. 2 .

131. Ibid, February 5, 1870, p. 4; March 26, 1870, p. 1 . See also Barbara Welter's excellent article, "The cult of True Womanhood, 1820-1860". American Quarterly, Summer, $1966,151-174$.

132. Ibid, May 29, 1879, p. 3 .

133. The New Northwest, July 3, 1879, p. 2.

134. Sentinel, July $2, i 870$, p. 2.

135. See Amy Kesselman's thesis, especially chapters four and five, for a theory of a "female culture" that developed in the context of the sexual segregation characteristic of families going West.

136. Arensberg, p. 90 .

137. City Directory, 1881, p. 32-33. Black men in Portland also had an association from at least 1874 called The United Sons of Love and Charity (see City Directory, 1875). 
138. Sentinel, June 22, 1876, p. 5 .

139. Whalen, p. 85-90.

140. For evidence of the semi-official attitude against mixed marriage, see the Sentinel of February 7, 1878, p. 3, in which an article is reprinted from an Eastern periodical which describes the alleged environment of a home in which the husband is a Protestant; his wife a Catholic:

The wife and children never hear the name of the Creator except in anger, and their consciences are constantly outraged by the infidel teachings and horrid mockeries of him who is their "lord and master' . . the home of such a family is a hell upon earth.

The question of why intermarriage in the United States in the middle and late l9th century almost always occurred between Catholic women and Protestant men is an important subject but outside the bounds of this thesis.

141. See, for example, Earl Pomeroy. The Pasific Slope. New York: Alfred Knopf, 1965, p. 284-5; Merriam, P. 71-73.

142. Pomeroy, p. 285.

143. Sentinel, October 10,1870, p. 3 .

144. The New Northwest, August 22, 1873, p. 2; August 29, 1873, p. 4 .

145. Merriam, p. 70. These incidents were reported by the influential judge, Matthew Deady.

146. The New Northwest, August 22, 1873, p. 2.

147. Merriam, p. 73. Merriam argues convincingly that this anti-monopolistic swipe was inspired by the small-businessorientation of most of the councillors. Irish store-owners and saloon-keepers were prominent supporters of Democratic council candidates.

148. Feller, p. 73.

149. Herbert Gutman. "Work, Culture, and Society in Industrializing America, 1815-1919", p. 572; Shannon, p. 36.

150. Sentinel, February 25, 1871, p. 3.

151. Ibid, September 4, 1874, p. 4 . 
152. Ibid, September 13, 1877, P. 4.

153. David Tyack. "Bureaucracy and the Common School: The Example of Portland, Oregon, 1851-1913". American Quarterly, XIX, 3 (Fall, 1967), P. 488. Tyack takes the position that the bureaucratic regimentation in portland public schools was instituted as a means of social control and as a method of channeling young people into the industrial system in a docile, malleable state. Information on the curriculum in 1873 can be found in Charles N. Reynolds, "Portland Public Schools, 1845-1871", p. 344-345.

154. "Catalogue of St. Mary's Academy, 1892-1893". Portland: F. W. Baltes and Co., p. 6.

155. Sentinel, December 2, 1875, p. 3. McCormick also criticized native-born Irish-American children for neglecting to bury their relatives with proper religious rites. See, for example, Sentinel, May 3, 1877, p. 3 .

156. The number of widowers in the same period was smaller: 7.48 .

157. Wright, Appendix B (no page number).

158. John F. Kilkenny. "Shamrocks and Shepherds: The Irish of Morrow County". Oregon Historical Quarterly, LXIX, 2 (June, 1968), p. 111.

159. Merriam, p. 286.

160. Clark, p. 99.

161. Wright, p. 62 .

162. For London, see Lynn H. Lees, "The Pattern of LowerClass Life: Irish Slum Communities in 19th Century London". Nineteenth-Century Cities, Edited by Stephan Thernstrom and Richard Sennett. New Haven: Yale University Press, 1969. For Boston, see Handlin, Boston's Immigrants. 
SOURCES CONSULTED

Books

Adams, W.F. Ireland and Irish Emigration to the New World from 1815 to the Famine. New York: Macmilian and Co., $19 \overline{32}$.

Arensberg, Conrad. The Irish Countryman: An Anthropological Study. New York: MacMillan and Co., 19 37.

Arensberg, Conrad and Kimball, Solon. Family and Community in Ireland. Cambridge: Harvard University Press, 1968 (first pub., 1940).

Aries, Philippe. Centuries of Chilahood: A Social History of Family Life. New York: Vintage Books, 1962.

Bagley, E.B. editor. Early Catholic Missions in Old Oregon, Vol. I. Seattle: Lowman and Hanford Co., $1 \overline{932}$.

Bancroft, Hubert Howe. History of Oregon, Vol. II (1848-1888). San Francisco: The History Co., 1888.

Bell, Norman W. and Vogel, Ezra F., editors. A Modern Introduction to the Family. Glencoe, Illinois: The Free Press, $1 \overline{960}$.

Calhoun, Arthur W. A Social History of the American Family. New York: Barnes and Noble, 1945 (First pub., 1917)

Clark, Dennis. The Irish in Philadelphia: Ten Generations of Urban Exper ience. Philadelphia: Temple University

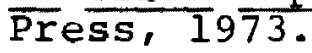

Coleman, Terry. Going to America. Garden City, New York: Anchor Press, 1973.

Colum, Padraic, editor. A Treasury of Irish Folklore. New York: Crown Publishers. 1954.

Demos, John. A Little Commonwealth. New York: Oxford University Press, 1970.

Ditzion, Sidney H. Marriage, Morals, and Sex in Amerira: $\underline{A}$ History of Ideas. New York: Octagon Books, 1969.

Duff, John B. The Irish in the United States. Belmont, Calif.: Wadsworth Publishing co., I971. 
Giles, Henry. Lectures and Essays on Irish and Other Subjects. New York: D\& J Sadlier Co., $186 \overline{9}$.

Gleanings of Fifty Years: The Sisters of the Holy Names of Jesus and Mary in the Northwest, 1859-1909. Portland: Glass and Prudhomme co., 1909.

Goode, William J. The Family. Englewood Cliffs, New Jersey: Prentice Hall, Inc., 1964.

Greeley, Andrew M. That Most Distressful Nation: The Taming of the American Irish. Chicago: Quadrangle Books, 1972.

Greven, Philip J., Jr. Four Generations: Population, Land, and Family in Colonial Andover, Massachusetts. Ithaca, New York: cornell University Press, 1970.

Handlin, Oscar. Boston's Immigrants. New York: Atheneum, 1969 (first Pub., 1941).

Higham, John. Strangers in the Land: Patterns of American Nativism, 1860-1925. $\overline{\text { New }}$ Brunswick, New Jersey: Rutgers University Press, 1955.

Humphreys, Alexander J. New Dubliners: Urbanization and the Irish Family. New York: Fordham University Press, 1966.

Hutchinson, E.P. Immigrants and Their Children, 1850-1950. New York: John Wiley and Sons, Inc., 1956.

Jackson, John Archer. The Irish in Britain. London: Routledge and Kegan Paul, $1 \overline{967}$.

Johansen, Dorothy o. Empire of the Columbia. New York: Harper and Row, 1967.

Jones, Maldwyn Allen. American Immigration. Chicago: University of Chicago press, $196 \overline{0}$

Levine, Edward M. The Irish and Irish Politicians. Grand Forks, North Dakota: University of North Dakota Press, 1966.

Lockley, Fred. History of the Columbia River Valley from the Dalles to the Sea, Vols. I and II. Chicago: The S.J. Clarke Publishing Co., $19 \overline{2} 8$.

Lyman, Horace S. History of Oregon, Vol. IV. New York: The North Pacific Publishing Co., 1903.

Maddux, Percy. City on the Willamette. Portland: Binfords \& Mort, 1952 .

McCarthy, Justin. Irish Recollections. New York: Hodder and 
Stoughton, no date (c. 1919).

Mitchell, Juliet. Woman's Estate. New York: Vintage Books, 1973.

Nichols, Leona M. The Mantle of Elias. Portland: Binfords \& Mort, 1941 .

O'Brien, Gecrge. The Economic History of Ireland from the Union to the Famine. London, New York: Longmans, Green, and Co., $\overline{1921 .}$

O'Faolain, Sean. The Irish, $\underline{A}$ Character Study. New York: Devin-Adair, $194 \overline{9}$.

O'Hara, Edwin V. Francis Norbert Blanchet, the Apostle of Oregon. Baltimore: J.H. Furst, 1910.

- Pioneer Catholic History of oregon. Portland: Glass and Prudhomme, 1911.

Pomeroy, Earl. The Pacific Slope. New York: Alfred Knopf, 1965.

Potter, George w. To the Golden Door: The Story of the Irish in Ireland and America. Boston: Litte, Brown, and Co., $196 \overline{0 .}$

Purdy, Rose Fay. The Rose City of the World. Portland: Binfords \& Mort, $19 \overline{47}$.

Rabb, Theodore K. and Rotberg, Robert I., editors, The Family in History, Interdisciplinary Essays. New York: Harper Torchbooks, 1973 .

Schrier, Arnold. Ireland and the American Emigration, 18501900. Minneapolis: University of Minnesota Press, 1958.

Sennett, Richard. Families Against the City. Cambridge: Harvard University Press, 1970.

Shannon, James P. Catholic Colonization on the Western Frontier. New Haven: Yale University press, 1957.

Shannon, William V. The American Irish. New York: Macmilian and Co., 1963.

Smith, Cecii Woodham. The Great Hunger. New York: Harper and Row, 1962 .

Thernstrom, stephan. Poverty and Erogress: Social Mobility in a Nineteenth-Century City. Cambridge: Harvard university Press, 1964 . 
Thomas, John L., S.J. The American Catholic Family. Englewood Cliffs, New Jersey: Prentice Hall, Inc., 1956.

Ward, Leo R. Holding Up the Hills: The Biography of a Neighborhood. New York: Sheed and ward, 1941 .

Wittke, Carl. The Irish in America. Baton Rouge, Louisiana: Louisiana State University Press, 1956.

Wrigley, E.A., editor. An Introduction to English Historical Demography. New York: Basic Books, 1966.

Writers' Program of the Works Project Administration. Oregon, End of the Trail. Portland: Binfords \& Mort, 1940 .

\section{Articles}

Bloomberg, Susan C., et al. "A Census Probe Into 19th-Century Family History: Southern Michigan, 1850-1880". Journal of Social History, V. 1 (Fall, 1971), 26-45.

Bridges, William E. "Family Fatterns and Social Values in America, 1825-1875". American Quarterly, XVII, l (Spring, 1965), 3-11.

Conway, Jill. "Women Reformers and American Culture, 18701930". Journal of Social History, V. 2 (Winter, 19711972), 164-177.

Douglas, Jesse. "Origins of the Population of Oregon in $1850^{\text {". }}$ Pacific Northwest Quarterly, XLI, 2 (April, 1950), 95-108.

Douglass, Paul H., et al. "The Portlana Church Survey". Portland: Portland Council of Churches, 1945.

Gordon, Linda. "Voluntary Motherhood: The Beginnings of Feminist Birth Control Ideas in the United States". Feminist Studies, I, 3-4 (Winter-Spring, 1973), 5-22.

Kerr, Thomas. "An Irishman in the Gold Rush: The Journal of Thomas Kerr". Quarterly of the California Historical Society, VII, 3 (September, 1928), 205-229; VIII, passim.

Kilkenny, John F. "Shamrocks and Shepherds: The Irish of Morrow County". Oregon Historical Quarterly, LXIX, 2 (June 1968), 101-147.

Lees, Lynn H. "Patterns of Lower-Class Life: Irish Slum Communities in 19th Century London". Sennett, Richard and Thernstrom, Stephan, editors. Nineteenth-Century Cities. New Haven: Yale University Press, 1969. 
McLaughlin, Virginia Yans. "Patterns of Work and Family organization Among Buffalo's Italians". Journal of Interdisci-

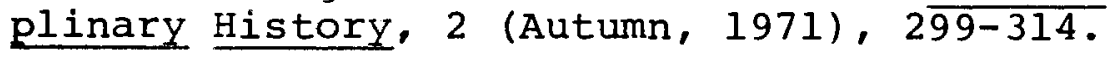

Messenger, John C. "Sex and Repression in an Irish Folk Cornmunity". Marshall, Donald S. and Suggs, Robert C., editors. Human Sexual Behavior. New York: Basic Books, Inc., $1 \overline{971 .}$

O'Meara, Edward F. "Continue to Prosper -- The History of the First Half Century of All Saints Parish, Portland, oregon". Portland: no publisher, no date (c. 1971).

Reynolds, Charles N. "Portland Public Schools, 1845-1871". Oregon Historical Society, XXXIII (December, 1932), $336-358$.

Saveti, Edward N. "The Problems of American Family History". American Quarterly, XXI (Summer, 1969), 311-329.

Tyack, David. "Bureaucracy and the Common School: The Example of Portland, Oregon, 1851-1913". American Quarterly, XIX (Summer, 1967), 475-498.

Walkowitz, Daniel J. "Working-Class Women in the Gilded Age: Factory, Community and Family Life Among Cohoes, New Ÿork, Cotton Workers". Journal of Social History, V. 4 (Sunmier, 1972), 464-490.

Unpublished Material

Feller, Daniel M. "Get a Job: Occupational structure and Social Mobility in Portland, Oregon, 1860-1880". Reed College B.A. Thesis, May, 1972.

Kesselman, Amy. "Diaries and Reminiscences of Women on the oregon Trail: A Study in Consciousness". Portland State University, M.A. Thesis, 1974.

McLaughlin, Virginia Yans. "Working-Class Immigrant Families: First Generation Italians in Buffalo, New York". Paper delivered before the annual convention of the organization of American Historians, April, 1971.

Merriam, Paul G. Portland, Oregon, 1840-1890: A Social and Economic History. University of Oregon, $\overline{\text { PhD Disserta- }}$ tion, 1971.

Whalen, Willis I. "The Pioneer Period of the Catholic Church in Portland, Oregon, 1851-1881". University of Portland, M.A. Thesis, 1950 . 
Wright, Mary C. "The World of Women: Portland, Oregon, 18601880". Portland State University, M.A. Thesis, 1973. 
APPENDIX : Sample Data Form

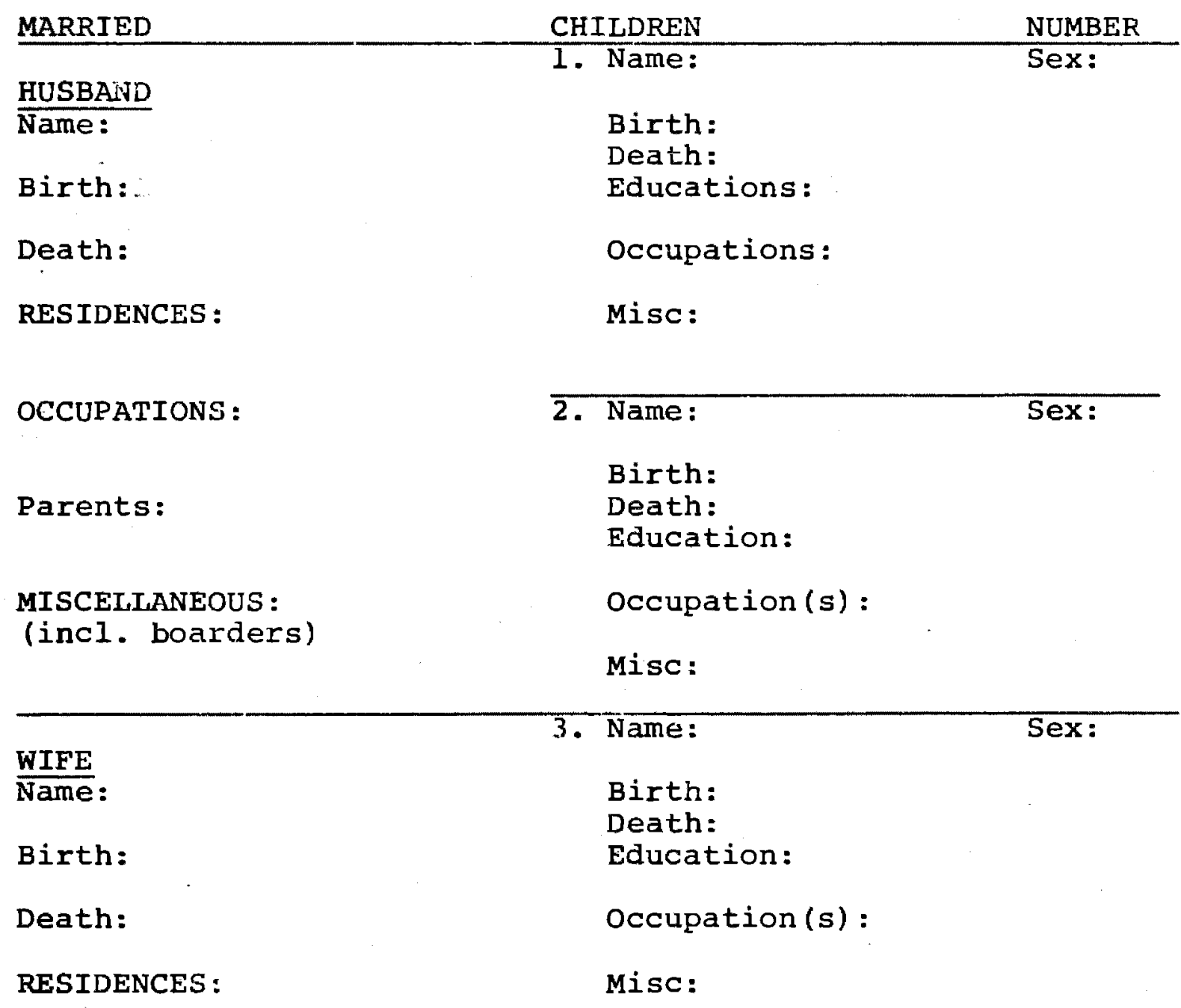

OCCUPATIONS :

Parents:

MISCELLANEOUS :

(incl. boärders)
4. Name: Sex:

Birth:

Death:

Education :

Occupation (s) :

Misc:

5. Name:

Sex:

Birth :

Death :

Education:

Occupation (s)

Miscellaneous: 